ORNL/Sub/90-90OR21954/1

Genetic Improvement of Switchgrass and Other Herbaceous Plants for Use as Biomass Fuel Feedstock

Final Report

K. P. Vogel

H. G. Jung

Environmental Sciences Division

September 2000 
ORNL/Sub/90-90OR21954/1

\title{
Genetic Improvement of Switchgrass and Other Herbaceous Plants for Use as Biomass Fuel Feedstock
}

\author{
Final Report
}

\author{
Kenneth P. Vogel \\ USDA-ARS \\ University of Nebraska \\ 344 Keim Hall \\ Lincoln, Nebraska \\ Hans-Joachim G. Jung \\ USDA-ARS \\ University of Minnesota \\ 411 Borlaug Hall \\ 1991 Upper Buford Circle \\ St. Paul, Minnesota
}

Environmental Sciences Division

Date Published: September 2000

Prepared for the

U.S. Department of Energy

Office of Fuels Development

Activity No. EB 5203000

Prepared by

Bioenergy Feedstock Development Program

Environmental Sciences Division

OAK RIDGE NATIONAL LABORATORY

Oak Ridge Tennessee 37831

managed by

UNIVERSITY OF TENNESSEE-BATTELLE, LLC

for the

U.S. DEPARTMENT OF ENERGY

under contract DE-AC05-00OR22725 



\title{
CONTENTS
}

\begin{abstract}
Page
EXECUTIVE SUMMARY $\ldots \ldots \ldots \ldots \ldots \ldots \ldots \ldots \ldots \ldots \ldots \ldots \ldots \ldots \ldots \ldots \ldots$

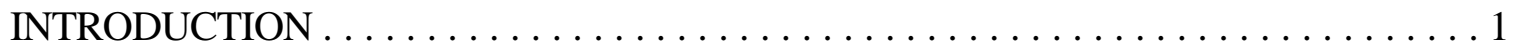

COMPOSITION, DEVELOPMENT, AND DISTRIBUTION

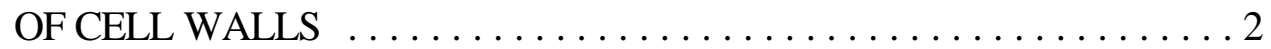

DEVELOPMENTAL AND ENVIRONMENTAL FACTORS

THAT AFFECT SWITCHGRASS BIOMASS QUALITY . . . . . . . . 4

MODIFICATION OF SWITCHGRASS BIOMASS QUALITY VIA

TRADITIONAL PLANT BREEDING METHODS $\ldots \ldots \ldots \ldots \ldots \ldots 7$

UTILIZATION OF GENETIC MARKERS TO ENHANCE PLANT

BREEDING EFFECTIVENESS $\ldots \ldots \ldots \ldots \ldots \ldots \ldots \ldots \ldots$

MODIFYING SWITCHGRASS QUALITY USING PLANT TRANSFORMATION

TECHNOLOGIES . . . . . . . . . . . . . . . . . . . . . . . 19

Potential Targets for Molecular Manipulation . . . . . . . . . . . . . 20

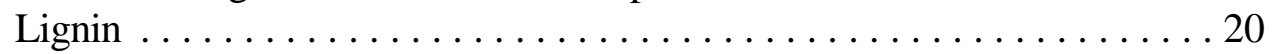

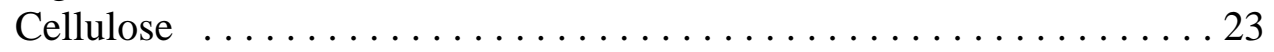

Other Cell-Wall Polysaccharides . . . . . . . . . . . . . . . 24

ENVIRONMENT AND ECOSYSTEM CONSTRAINTS ON THE USE OF

GENETICALLY MODIFIED ORGANISMS . . . . . . . . . . . 27

DEVELOPMENT OF A BIOMASS FEEDSTOCK QUALITY

ASSESSMENT PROGRAM FOR DETERMINING

AND MONITORING FEEDSTOCK QUALITY .28

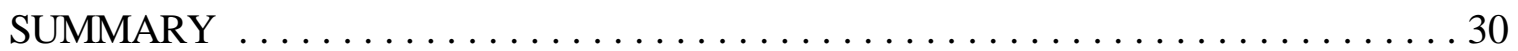

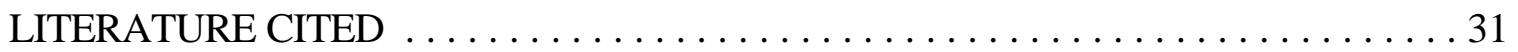





\section{LIST OF FIGURES}

Figure

Page

1 Animal production increases exponentially with improvements in forage digestibility. Digestible energy (DE) intake values are for $300 \mathrm{~kg}$ beef steer. The darker shaded area represents maintenance requirements. . . . . . . . . . . 2

2 In vitro dry matter digestibility (IVDMD) and ferulic acid/p-coumaric acid (FA/PCA) ratio in grazed switchgrass forage of three different strains during 1983, 1984, and 1985. Correlation coefficients $(r)$ are for linear (IVDMD) and quadratic (FA/PCA) regressions with maturity, respectively, analyzed across strains. Note scale differences for IVDMD. The LSD is for

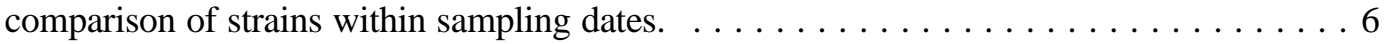

3 Divergent phenotypes of populations selected for different levels of in vitro dry matter disappearance of lignin concentration (expressed as a proportion of the cell wall, CW). Eacy cycle of selection represents identification of parents with either high $(+1)$ or low (! 1) in vitro dry matter disappearance, followed by intercrossing and evaluation of progeny. Cycle 0 represents the original population. All responses were linear with $\mathrm{P}<0.05$. Alfalfa data are means over three environments (14), bromegrass data are means over four environments (15), orchardgrass data are means over give environments (16), and switchgrass data are means over eight environments (17). Lignin data were not available for the orchardgrass populations. The cycle 2 high-IVDMD switchgrass selection was not available for

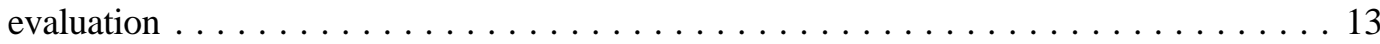

$4 \quad$ Fitness of divergent-IVDMD selections. Each cycle of selection represents identification of parents with either high $(+1)$ or low(! 1) IVDMD, followed by intercrossing and evaluation of progeny. Cycle 0 represents the original population. All responses were linear with $\mathrm{P}<0.05$. Each data point represents a mean over four replicates and three locations (18). (A) Survival of orchardgrass transplants at three sampling dates. approximately 4, 17, and 48 months after transplanting. (B) Survival of switchgrass transplants at four sampling dates, approximately 12, 24, 36, and 48 months after transplantiing. (C) Aboveground biomass of switchgrass transplants (means over 2 years) $\ldots \ldots \ldots \ldots \ldots \ldots \ldots$

5 A schematic representation of the lignin biosynthetic pathway starting from phenylalanine (Phe). Tyrosine is the second precursor to this pathway via tyrosine ammonia lyase to form $p$-coumaric acid. The enzymes involved in lignin synthesis include: PAL, phenylalanine ammonia lyase; $\mathrm{C} 4 \mathrm{H}$, cinnamate 4-hydroxylase; $\mathrm{C} 3 \mathrm{H}$, 4-coumaroyl hydroxylase; OMT, $O$-methyltransferase; $\mathrm{F} 5 \mathrm{H}$, ferulate 5-hydroxylase; $4 \mathrm{CL}$, 4-coumarate-CoA ligase; CCoA3H, 4-coumaroyl-CoA hydroxylase; CoAOMT, caffeoylCoA $O$-methyltransferase; CCR, cinnamoyl-CoA reductase; CAD, cinnamyl alcohol dehydrogenase, and peroxidase. The bold arrows indicate the major route of lignin synthesis as proposed by Chiang and co-workers (Osakabe et al. 1999; Li et al. 1999; Li et

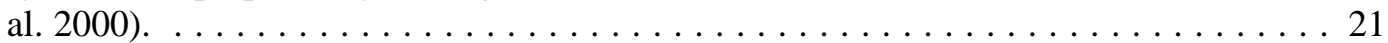




\section{LIST OF FIGURES (cont'd)}

Figure

Page

6 The biosynthetic pathway for the major sugars that serve as cell-wall polysaccharide precursors. The enzymes involved in these sugar interconversions include: phosphoglucomutase (1); UDP-glucose pyrophosphorylase (2); UDP-glucose dehydrogenase (3); UDP-glucuronic acid decarboxylase (4); UDP-glucose epimerase (5); UDP-glucuronic acid epimerase (6); UDP-xylose epimerase (7); mutase (8); GDP-mannose pyrophosphorolase (9); GDP-mannose-4,6-dehydratase (10); 3,5 epimerase (11); 4-reductase (12); 1-myo-inositol 1-P synthase (13); myo-inositol 1-phosphatase (14); myo-inositol oxygenase (15); glucuronokinase (16);

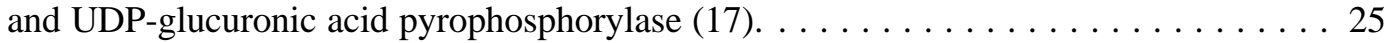




\section{LIST OF TABLES}

$\begin{array}{lll}\text { Table } & \text { Page }\end{array}$

1 Effect of maturity on composition of leaf and stem tissue of switchgrass $\ldots \ldots \ldots 5$

2 Concentrates of neutral sugars in cell-wall hydrolysates from ammoniated switchgrass herbage harvested at heading at Lincoln, Nebraska, as affected by genetic strain averaged over ammoniation rates of $0,10,20,40 \mathrm{~g} \mathrm{~kg}^{-1}$

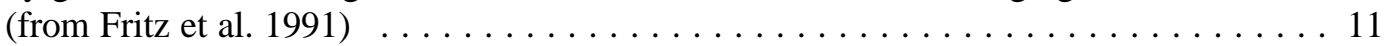

3 Mean biomass yield, IVDMD, digestible yield, and holocellulose yield for switchgrass strains grown at three midwest locations and harvested at heading which were selected for IVDMD or yield and IVDMD . . . . . . . . 12

4 Multiyear means and range values for herbage yield, herbage in vitro dry matter digestibility, and survival percentages for half-sib progeny of EY x FF High IVDMD C3 switchgrass parent plants and the check populations, EY x FF Low IVDMD C-1, Trailblazer, and EY x FF High IVDMD C3 parent bulk population 



\section{EXECUTIVE SUMMARY}

Switchgrass, a perennial warm-season grass native to the prairies of North America, has been identified by the U.S. Department of Energy (DOE) as its main species of emphasis for development into a herbaceous biomass fuel crop. Switchgrass and other herbaceous plant biomass will be a raw agricultural commodity that must be converted into a liquid fuel, probably ethanol, via conversion technology still under development. If feedstock quality can be genetically improved, the economics and efficiency of the conversion process could be significantly enhanced.

Genetically improving an agricultural product for improved end product use requires knowledge of desired quality attributes; the relative economic value of the quality parameters in relation to yield, genetic variation for the desired traits, or for molecular breeding; knowledge of genes to suppress or add; and knowledge of any associated negative consequences of biomass quality manipulation. Because technology is still under development for conversion of herbaceous biomass to liquid fuels, desirable plant feedstock characteristics have not been completely delineated. Some traits such as cellulose and lignin concentration will undoubtably be important.

Much of the research on the genetic modification of herbaceous plant cell walls has been conducted to improve the utilization of forages by ruminant livestock including beef and dairy cattle and sheep. The rumen of these animals is basically an anaerobic fermentation vat in which the microflora break down the complex polysaccharides of plant cell walls into simpler compounds that can be further digested and absorbed by other organs in the digestive system. Research on improving the forage digestibility of switchgrass and other herbaceous species has demonstrated that genetic improvements can be made in forage quality that can have significant economic value.

It should be highly feasible to genetically modify the feedstock quality of switchgrass and other herbaceous plants using both conventional and molecular breeding techniques. The use of molecular markers and transformation technology will greatly enhance the capability of breeders to modify the morphologic structure and cell walls of herbaceous species. It will be necessary to monitor gene flow to remnant wild populations of biomass plants and have strategies available to curtail gene flow if it becomes a potential problem. It also will be necessary to monitor plant survival and long term productivity as affected by genetic changes that improve biomass quality.

In addition to improving feedstock quality genetically, management procedures to optimize biomass quality in field production, harvesting, storage, and transportation components of the overall production system will be needed. A feedstock quality assessment program to rapidly determine feedstock quality at the farm or factory gate will be needed to ensure that feedstock of desired quality is used in conversion plants. It also would enable conversion plants to pay producers for both quality and tonnage.

\section{Research Recommendations}

1. Determine herbaceous feedstock characteristics that affect conversion efficiency and rate their relative economic value. Conversion research facilities should routinely use switchgrass biomass samples obtained as per Recommendation 2 in their research. Rapid, inexpensive methods of assaying for the principal traits (cellulose, lignin, conversion efficiency) such as near infrared reflectance spectroscopy (NIRS) need to be evaluated, modified, or developed to facilitate biomass quality evaluation for the thousands of plants that are examined in genetic improvement and evaluation programs.

2. Biomass samples for use in conversion research need to be collected at various stages of development from an array of characterized environments and storage conditions for target herbaceous species such as switchgrass and from genotypes within species known to differ genetically for biomass quality characteristics. A laboratory with extensive prior experience in 
forage quality research should lead this effort and serve as the primary interface with conversion laboratories such as National Research Energy Laboratory (NREL). Feedstock development research projects would provide samples as per specific protocols. The lead laboratory would characterize samples by NIRS analysis and other emerging rapid, automated analytical technologies and develop calibrations and procedures that could be used in breeding and genetic studies and also for eventual use in buying feedstocks on a quality basis.

3. Conventional breeding and genetic studies to date on forage or biomass quality have used the detergent system of analysis to determine lignin, cellulose, and hemicellulose concentrations. Recent research has clearly shown that acid detergent lignin underestimates lignin concentration which results in an over-estimation of cellulose and hemicellulose concentrations. Genetic studies using both divergent selection and parent-progeny analysis need to be conducted on target species to determine the genetic variation for Klason lignin and other biomass energy specific traits. Because of the large numbers of plants that will need to be analyzed, NIRS calibrations developed via Recommendations 1 and 2 will be needed for plant analysis. Breeding work would then need to be initiated for those traits for which genetic variation indicates genetic gains are feasible.

4. Molecular genetics technology should be used in several thrust areas. Molecular marker maps of switchgrass and other principal herbaceous species need to be developed to enable genetic differences identified via Research Recommendation 3 to be linked to specific genetic markers and utilized in marker assisted selection. The genetic markers will be needed to monitor potential gene flow from biomass crops with modified cell-wall traits to wild populations. Research on developing robust genetic maps and associated sets of markers are being initiated and should continue to receive support.

5. Lignin and cellulose synthase genes are being mapped and cloned by various research groups in an array of species. The impact of the use of these genes in candidate perennial biomass crops such as switchgrass and alfalfa need to be tested and evaluated. The research to date with herbaceous transgenic plants has been primarily on annuals. It should be feasible to determine the effect of the genes on feedstock quality, plant yield, and other traits of transformed plants by using vegetative ramets or clonal propagules of the transformed plants. Genes with desirable characteristics could then be evaluated for any potential deleterious environmental effects and if none, then used directly in genetic improvement programs.

6. To date, only seven genes (five for monomer synthesis, two for polymer assembly) have been cloned for cell-wall polysaccharide synthesis. Only one screen in a mutagenized Arabidopsis population has been done for cell-wall monosaccharide composition. Systematic screening for cell-wall mutants has not been done in grasses other than for brown mid-rib genes. Additional genes, including genes that control cell-wall composition as well as timing, site and extent of deposition of polysaccharides and lignin in cell walls very likely exist. Screening research for cell-wall mutants in $\mathrm{C}_{3}$ and $\mathrm{C}_{4}$ grasses and legumes should be initiated. Emphasis should be on diploid, perennial species because any genes identified would already be capable of being used in a perennial such as switchgrass and because finding mutants in plants with high ploidy levels is extremely difficult. As an example, Medicago truncatula, a close diploid relative of alfalfa, could be used to identify cell-wall mutants because mutagenized populations are already available and large-scale gene sequencing is under way.

7. Research on harvesting and storage methods for maintaining and preserving quality needs to be initiated in all potential production areas. Affects of storage conditions on feed stock quality 
using the quality parameters identified in Research Recommendation 1 needs to be clearly delineated.

8. Economic analyses will need to be conducted to determine the relative economic value of improved biomass quality vs yield because improving biomass quality could limit the rate of genetic improvement in biomass yield currently being achieved by plant breeders and could also limit maximum yields. Breeders, geneticists, and production agronomists need to be able to apply economic weights to yield and quality factors in order to optimize biofuel yield both per acre and ton of feedstock.

9. Herbaceous plants are likely going to be modified to produce bio-products such as biodegradable plastics and vaccines. These products will likely have higher market value than liquid fuels from biomass. It would be extremely difficult to genetically modify plants for two or more different end uses. Rather that attempt to develop biomass plants with specific coproducts, the biofuels program should instead concentrate on determining the bioenergy value of the residues derived from processing plants developed for other bioproducts. A notable exception is that attention could be focused on developing transgenic plants to produce the enzymes (cellulases and xylanases) needed to produce liquid fuels from biomass. These enzyme producing biomass plants must be capable of high levels of protein production, such as alfalfa, and could be directly combined with specialized biofuels species, such as switchgrass, during conversion or used as a source for enzyme extraction. 



\section{INTRODUCTION}

Switchgrass (Panicum virgatum L.), a perennial warm-season grass native to the prairies of North America, has been identified by the U.S. Department of Energy (DOE) as its main species of emphasis for development into a herbaceous biomass fuel crop. Switchgrass biomass feedstock will be a raw agricultural commodity that will be need to be converted into a liquid fuel, probably ethanol, via conversion technology still under development. Depending on the conversion technology that is used, there will be byproducts that may have positive or negative economic value. If feedstock quality can be genetically modified, the efficiency of the conversion process could be enhanced resulting in more desirable primary or secondary products and reduced undesired byproducts. The objective of this report is to evaluate the feasibility of improving feedstock quality of switchgrass and other herbaceous plants for conversion to biomass fuels by classical selection and breeding and/or genetic transformation. The report will focus on switchgrass but will be applicable to other herbaceous species that may be developed into biofuel crops in the future. The areas that will be covered in this report include:

1. Composition, development, and distribution of cell walls in herbaceous plant;

2. Developmental and environmental factors that affect switchgrass and other herbaceous biomass quality;

3. Modification of switchgrass biomass quality via traditional plant breeding methods;

4. Utilization of genetic markers to enhance plant breeding effectiveness;

5. Modifying switchgrass quality using plant transformation technologies;

6. Environment and ecosystem constraints on the use of genetically modified organisms; and

7. Development of a "Biomass Feedstock Quality Assessment Program" for determining and monitoring feedstock quality.

In most industrial applications, the conversion technology that will be used to convert a raw agricultural product into a finished product and the feedstock parameters that need to be modified to improve conversion efficiency are known before a plant breeding effort is initiated. Since conversion technology is still under development and desirable plant feedstock characteristics have not been delineated, this report will discuss potentially useful quality parameters that are likely to be amenable to genetic modification.

Much of the research on the genetic modification of herbaceous plant cell walls has been conducted to improve the utilization of forages by ruminant livestock including beef and dairy cattle and sheep. The rumen of these animals is basically an anaerobic fermentation vat in which microflora break down the complex polysaccharides of plant cell walls into simpler compounds that can be further digested and absorbed by other organs in the digestive system. Ruminants have energy requirements for maintenance and rumen capacity limits the amount of forage that can be digested in a day. Consequently, small improvement in the conversion or digestibility of forages in ruminants can significantly increase the digestible energy intake of animals which can lead to economically significant exponential increases in per animal milk or meat production, as illustrated in Fig. 1 (from Vogel and Moore 1993). Averaged over ten cultivars of both cool- and warm-season grasses including switchgrass, a $1 \%$ increase in vitro dry matter digestibility (IVDMD) resulted in a $3.2 \%$ increase in daily gains (Casler and Vogel 1999). The IVDMD test is an artificial rumen procedure that estimates the digestibility of a forage in ruminants. Since the degradation process in a ruminant is essentially a fermentation process, IVDMD is a trait that would likely be correlated to potential ethanol production from biomass via fermentation 


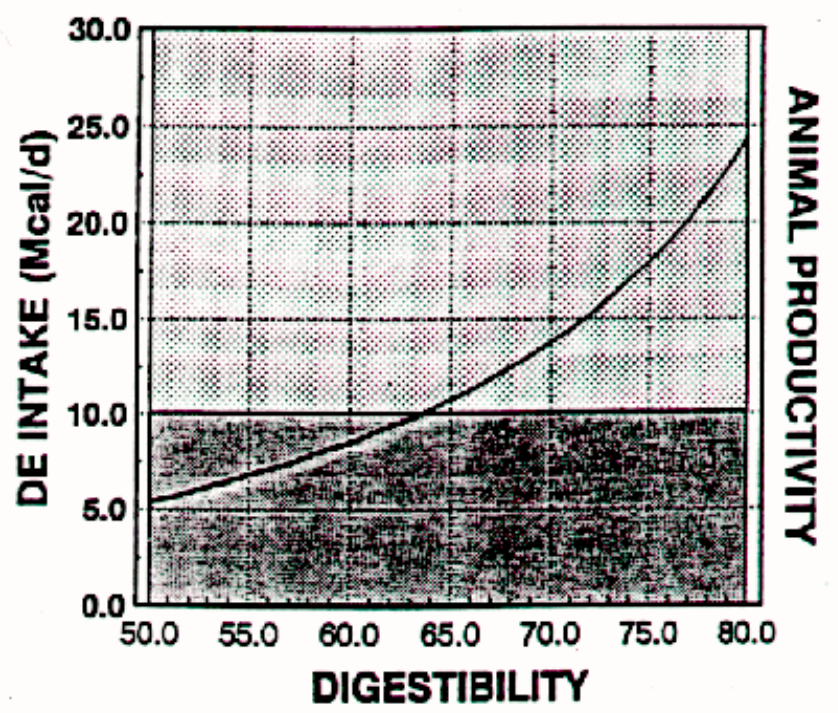

Fig. 1. Animal production increases exponentially with improvements in forage digestibility. Digestible energy (DE) intake values are for $300 \mathrm{~kg}$ beef steer. The darker shaded area represents maintenance requirements.

technologies. Improvements in biomass feedstock quality also may improve the efficiency of feedstock conversion plants. In regions that have the forage production potential of eastern Nebraska, a percentage unit increase in IVDMD in small plot trials has a potential economic value of $\$ 25 /$ ha to livestock producers when grown in pastures (Vogel and Sleper 1994). In contrast, the economic value of any change in cell wall composition for biomass conversion is unknown.

\section{COMPOSITION, DEVELOPMENT, AND DISTRIBUTION OF CELL WALLS}

The energy in herbaceous plant biomass is largely in plant cell walls. Cell walls comprise 40 to $80 \%$ of the biomass in herbaceous plants, depending on species and maturity of the plant material. Cellulose, hemicellulose, and pectin are the polysaccharide components of plant cell walls. Cellulose is composed of \$1,4 linked glucose. In contrast, hemicellulose and pectin are comprised of mixtures of both hexose and pentose sugars with a variety of linkage types (Hatfield 1993). Lignin, a phenolic polymer, is the other major constituent in walls. Smaller amounts of protein and minerals are also present. Grasses contain 1 to $2 \%$ hydroxycinnamic acids (ferulate and $p$-coumarate) in their cell walls and ferulates cross-link arabinoxylan to lignin (Jung and Deetz 1993; Ralph et al. 1998a). As plants mature, wall composition shifts from moderate levels of protein $(\sim 10 \%)$ and almost no lignin to very low concentrations of protein and substantial amounts of lignin (20 to 30\%). Cellulose typically represents $\sim 50 \%$ of the polysaccharide fraction in the cell wall of herbaceous plants. In grasses, the remaining polysaccharide is primarily hemicellulose with only small $(\sim 5 \%)$ amounts of pectin. Grass hemicellulose consists mostly of arabinoglucuronoxylans. In legumes and other dicotyledons, pectin accounts for 30 to $40 \%$ of the non-cellulosic polysaccharides and the hemicellulose consists primarily of xyloglucans.

It should be noted that much of the literature on cell-wall concentration and composition for agriculturally important grass and legume species is inaccurate because of the method of analysis 
typically employed. The compositional data presented earlier are based on methods that measure total cell-wall polysaccharides by acid hydrolysis and chromatographic determination of component neutral sugars, plus a spectrophotometric assay for acidic sugars (e.g., Theander et al. 1995). Lignin concentration is based on a gravimetric determination of the non-hydrolyzable residue (Klason lignin). More typically, the detergent system of analysis (Van Soest 1994) is used for analysis of grasses and legumes by agricultural scientists. Most of the pectin in the cell wall is lost by solubilization during the first step of the detergent system where neutral detergent fiber (NDF) is isolated. The relative amounts of cellulose, hemicellulose, and lignin are calculated by difference from sequential determinations of NDF, acid detergent fiber (ADF), acid detergent lignin (ADL), and ash. Because of incomplete solubilization of protein and hemicellulose by the NDF and ADF steps, respectively, calculation of hemicellulose and cellulose are biased by contaminants (Morrison 1980). The net result is that NDF is a reasonably accurate estimate of total cell wall for grasses because of the low concentration of pectin in grasses, but NDF significantly underestimates cell-wall concentration in legumes because of their higher pectin levels. Because of contamination problems, cellulose and hemicellulose estimates from the detergent system should be used with caution.

However, the greater error in the detergent system is that ADL under estimates lignin concentration by a factor of 2 to 4 times in grasses and 30 to $100 \%$ in legumes, compared to the Klason lignin method. A series of studies (Kondo et al. 1987; Hatfield et al. 1994; Lowry et al. 1994; and Jung et al. 1999b) have established that Klason lignin is the more accurate method for quantifying lignin in herbaceous plants. Use of ADL has resulted in substantial overestimates of polysaccharide content in grasses and other herbaceous plants due to underestimation of lignin content. For example, from the data of Hatfield et al. (1994) it can be calculated that using ADL, compared to Klason lignin, for determination of lignin concentration overestimated cell-wall polysaccharide content of switchgrass stems by $\sim 12 \%$. While ADL and Klason lignin concentration estimates are correlated ${ }^{\circledR}=0.75$, Jung et al. 1997a), we have not attempted to correct the ADL values drawn from literature sources cited in this review.

While herbaceous biomass increases in cell-wall concentration and lignin proportion of the wall during plant maturation, these changes do not occur in all tissues. In alfalfa (Medicago sativa L.) there are several tissues (epidermis, collenchyma, chlorenchyma, secondary phloem, cambium, and protoxylem parenchyma) that never lignify (Engels and Jung 1998); however, some of these tissues (epidermis and collenchyma) do develop thick cell walls during the maturation process. In the case of alfalfa collenchyma tissue, these thick mature cell walls are extremely rich in pectin. The majority of the cell-wall material in legume stems is in the xylem tissue which develops thick walls rich in cellulose, hemicellulose, and lignin. During cambial growth in dicots, this xylem tissue becomes an ever-increasing proportion of the stem with maturity (Engels and Jung 1998). Alfalfa has another unique tissue, primary phloem, that develops a very thick secondary wall that is extremely rich in cellulose, but contains no lignin (Engels and Jung 1998). If legumes could be genetically modified to alter the relative proportions of the tissues comprising the stem, then cell-wall composition could be dramatically shifted.

In contrast to legumes like alfalfa, grass tissues do not differ so dramatically in cell-wall composition. While the phloem and mesophyll tissue in grasses remains non-lignified, all other tissues lignify to some extent (Wilson 1993). Parenchyma bundle sheath cells are a specialized tissue in $\mathrm{C} 4$ grasses that thicken and lignify to varying extent depending on species. There are no non-lignified, pectin-rich tissues in grasses similar to those found in legumes. The best data available for cell-wall composition of grass tissues are from sorghum (Sorghum bicolor (L.) Moench) stems (Hatfield et al. 1999). While polysaccharide content and composition of the wall varied among tissues, the greater difference among tissues was in total cell-wall concentration. The potential for altering cell-wall polysaccharide content of grasses by shifts in tissue proportions appears to be less than in legumes. 
While maturity is the single most important determinate of cell-wall concentration and composition, other factors do change the amount and characteristics of plant cell walls. Plant morphology has a major impact on cell-wall concentration of forages due to differences between leaves and stems. For grasses such as big bluestem (Andropogon gerardii Vitman) and switchgrass, leaves have somewhat lower NDF concentrations ( $65 \%$ vs $75 \%$ ) than stems (Griffin and Jung 1983; Jung and Vogel 1992). In a legume such as alfalfa, the leaves have less than half the NDF content of the stems (Jung et al. 1997b). Another difference between grasses and legumes is that cell-wall concentration of grass leaves increases at almost the same rate as in stems (Jung and Vogel 1992), whereas legume leaves remain relatively constant in their leaf composition while stems deposit large amounts of additional cell-wall material with maturity (Kalu and Fick 1983). The proportion of lignin in the cell walls of legume leaves and stems do not differ (Jung et al. 1997b), but cell walls of grass stems do tend to be more lignified than leaves (Griffin and Jung 1983, Jung and Vogel 1992). Selection for a change in leaf-to-stem ratio will have dramatic effects on cell-wall concentration of the total herbage of legumes and smaller, but significant, effects on grass cell-wall concentration. Compositional changes in the cell wall are relatively small due to plant morphology.

\section{DEVELOPMENTAL AND ENVIRONMENTAL FACTORS THAT AFFECT SWITCHGRASS BIOMASS QUALITY}

Switchgrass is a photoperiod sensitive plant (Moser and Vogel 1995). It requires long days followed by short days to flower. Mitchell et al. (1997) sampled Trailblazer switchgrass and Pawnee big bluestem grown at Mead, Nebraska, in 1990 and 1991 at weekly intervals and staged the plant material for physiological maturity using the Nebraska staging system of Moore et al. (1991). Plants were staged for both mean stage count (MSC) and mean stage weight (MSW). Prediction equations for MSC and MSW based on day of the year (DOY) and growing degree days (GDD) were developed. The equations were validated in 1992 and 1993 using switchgrass and big bluestem stands at Mead, Nebraska, and Manhattan, Kansas. Linear DOY calibration equations accounted for $96 \%$ of variation for MSC for switchgrass indicating that switchgrass development is strongly influenced by photoperiod. Mitchell et al. (1997) concluded that switchgrass's general development can be reasonably well predicted in normal years by DOY estimates and that for switchgrass, general management practices can be based on DOY. For big bluestem, $83 \%$ of variation in MSC was due to DOY in a quadratic mode. It appears to be more affected by GDD and other environmental factors than switchgrass. For both species, MSC and MSW were strongly correlated. In switchgrass as in other grasses, physiological maturity at harvest has an effect on almost all herbage or biomass characteristics that have been analyzed to date. This includes IVDMD, NDF, hemicellulose, lignin and other traits (Table 1, Fig. 2) (Jung and Vogel 1992; Gabrielsen et al. 1990). 
Table 1. Effect of maturity on composition of leaf and stem tissue of switchgrass ${ }^{a}$

\begin{tabular}{|c|c|c|c|c|c|c|c|}
\hline $\begin{array}{l}\text { Tissue } \\
\text { type and } \\
\text { maturity }\end{array}$ & $\mathrm{NDF}$ & $\begin{array}{l}\text { Hemi- } \\
\text { cellulose }\end{array}$ & Cellulose & $\begin{array}{l}\text { Lignin } \\
\text { (ADL) }\end{array}$ & \multicolumn{2}{|c|}{$\begin{array}{l}\text { Esterified } \\
\text { p-coumaric ferulic } \\
\text { acid acid }\end{array}$} & $\begin{array}{l}\text { Nitro- } \\
\text { benzene } \\
\text { oxidation } \\
\text { yield }\end{array}$ \\
\hline & $\begin{array}{l}\mathrm{g} \mathrm{kg}^{-1} \\
\mathrm{DM}\end{array}$ & \multicolumn{3}{|c|}{--------- g kg $^{-1}$ NDF -------- } & \multicolumn{2}{|c|}{----g kg ${ }^{-1}$ NDF-- } & $\mathrm{g} \mathrm{kg}^{-1} \mathrm{ADL}$ \\
\hline \multicolumn{8}{|l|}{ Leaf } \\
\hline V & 614 & 495 & 455 & 40 & 4.05 & 4.53 & 78 \\
\hline B & 641 & 496 & 450 & 42 & 4.06 & 4.73 & 77 \\
\hline $\mathrm{H}$ & 682 & 493 & 436 & 54 & 3.63 & 3.82 & 46 \\
\hline \multicolumn{8}{|l|}{ Stem } \\
\hline V & 657 & 467 & 481 & 48 & 7.31 & 5.28 & 144 \\
\hline B & 723 & 417 & 510 & 75 & 9.58 & 4.38 & 106 \\
\hline $\mathrm{H}$ & 742 & 421 & 495 & 86 & 9.61 & 4.13 & 66 \\
\hline
\end{tabular}

${ }^{a} \mathrm{~V}=$ vegetative, $\mathrm{B}=$ boot, and $\mathrm{H}=$ heading stages of maturity (from Jung and Vogel 1991).

Mitchell et al. (2000) evaluated the effectiveness of using GDD, DOY, MSC, and MSW to predict IVDMD, crude protein (CP), and NDF of switchgrass and big bluestem grown in Nebraska and Kansas. The study was conducted for 3 years at Mead, Nebraska, and 2 years at Manhattan, Kansas, in 1990 to 1993. Plants were sampled weekly or biweekly, classified as MSC and MSW and analyzed for IVDMD, CP, and NDF. The traits IVDMD and CP were highly predictive by DOY and GDD for both species (all regressions were highly significant and $\mathrm{R}^{2}$ values were 0.92 or higher). NDF was predicted by DOY in switchgrass $\left(\mathrm{R}^{2}=0.70\right)$. Results indicate that switchgrass and big bluestem morphological development is largely driven by photoperiod which in the Central Great Plains is strongly associated with GDD. Because morphological development affects forage quality, as measured by IVDMD and CP, DOY and GDD can be used to estimate quality parameters of switchgrass biomass. Similar results have been obtained by Sanderson and Wolf (1995) who grew Alamo and Cave-in-Rock switchgrass in replicated trials at Stephenville, Texas, and Blacksburg, Virginia. Forage harvests were taken weekly during the growing season and analyzed for cell wall components. Their results demonstrate a close relationship between GDD and cell wall composition. In addition to switchgrass, the morphological development of most other forage species is sensitive to photoperiod (Nelson and Volenec 1995). In addition to photoperiod, morphological development also can be affected by other climate related factors including temperature and water stress (Nelson and Volenec 1995). 

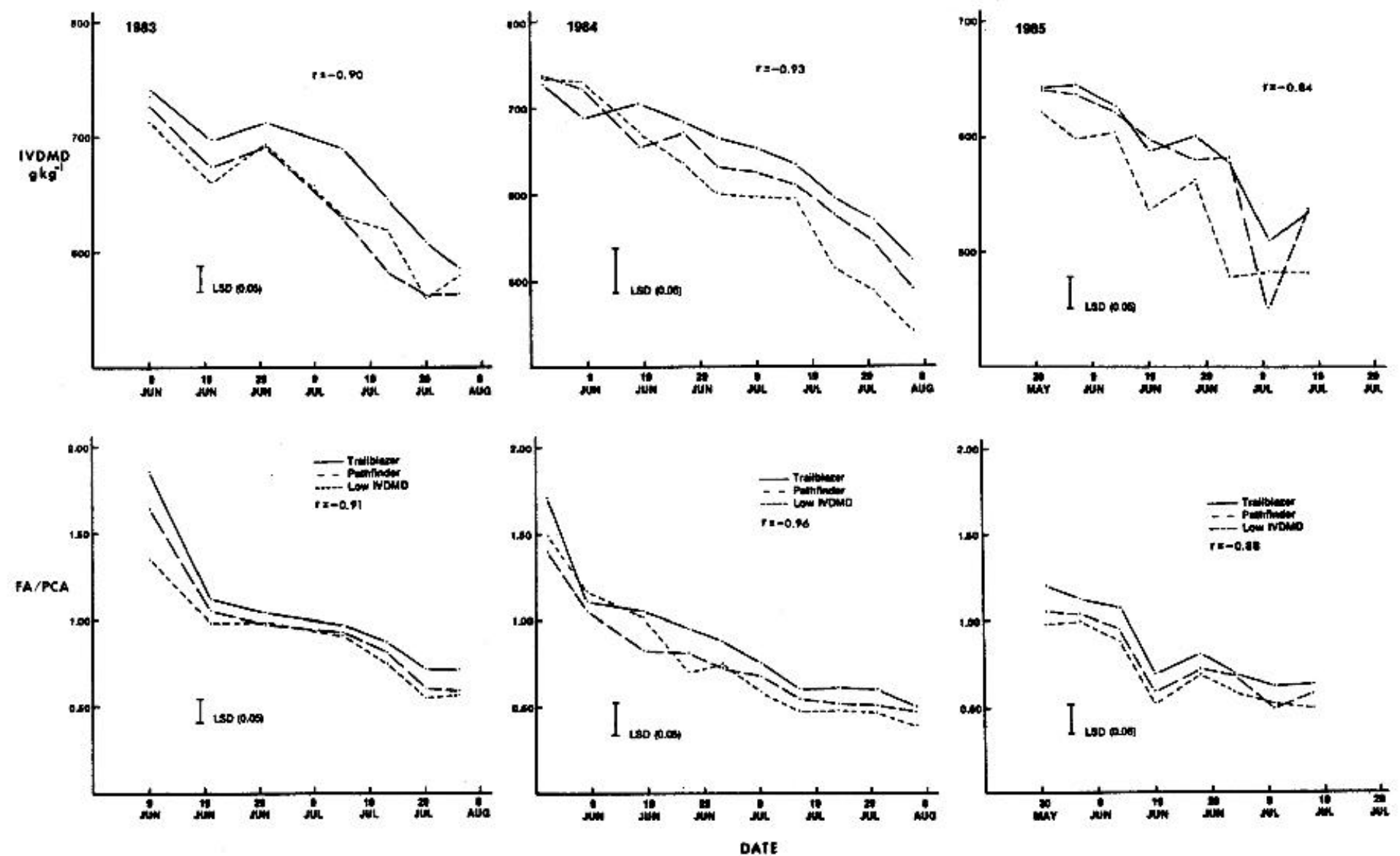

Fig. 2. In vitro dry matter digestibility (IVDMD) and ferulic acid/p-coumaric acid (FA/PCA) ratio in grazed switchgrass forage of three different strains during 1983, 1984, and 1985. Correlation coefficients ( $r$ ) are for linear (IVDMD) and quadratic (FA/PCA) regressions with maturity, respectively, analyzed across strains. Note scale differences for IVDMD. The LSD is for comparison of strains within sampling dates. 
Environmental growth conditions can influence cell-wall concentration and, to a lesser extent, composition. Buxton and Fales (1994) and Buxton and Casler (1993) have reviewed the impact of plant growth environment on cell-wall concentration and composition. Temperature is the environmental factor that most strongly effects plant cell walls, with high temperatures causing increased rate of reproductive maturation. A major impact of more rapid reproductive development is a reduction in leaf-to-stem ratio. High temperatures also result in higher cell-wall concentration, with increases occurring in both the polysaccharide and lignin fractions (Buxton and Fales 1994). Switchgrass leaves and stems had higher lignin and lower NDF digestibility when grown at 32EC in comparison to switchgrass grown at 22EC (Wilson et al. 1991). Moisture stress of alfalfa due to drought reduces cell-wall deposition relative to the normal accumulation that occurs with maturation while reproductive development proceeds, but composition of the wall is not affected (Halim et al. 1989; Deetz et al. 1994). Nitrogen fertilization increases total plant growth rate, but does not alter cell-wall development (Buxton and Fales 1994).

In the studies that have been conducted to date, genetic differences in forage quality parameters have been stable over environments, i.e., genotype $\mathrm{x}$ environment interactions have been small and usually nonsignificant (Vogel and Sleper 1994; Casler and Vogel 1999). Environment as described above does affect biomass quality factors such as IVDMD, but the genetic differences remain consistent over environment. This has been demonstrated in several studies with switchgrass (Hopkins et al.,1993 1995a,1995b; Gabrielsen et al. 1990; Vogel et al.1981) and is illustrated in Fig. 2 (from Gabrielsen et al. 1990). As illustrated in Fig. 2, the primary factor affecting both IVDMD and the FA/PCA ratio is plant maturation. There are year-to-year differences in the forage quality parameters shown (note difference in scale for IVDMD for 1985 vs 1983 and 1984), but the differences among strains remains consistent over years and within years.

Environmental conditions and management practices can interact to significantly affect dry matter losses and detrimental changes in quality of forage during storage (Collins and Moore 1995). Forages or biomass stored improperly can have dry matter losses from single digit percentages up to the $100 \%$ that occurs when hay stacks ignite due to spontaneous combustion. Improper storage conditions can reduce IVDMD by over 10 percentage units and increase ADL by over 5 percentage units (Collins and Moore 1995).

\section{MODIFICATION OF SWITCHGRASS BIOMASS QUALITY VIA TRADITIONAL PLANT BREEDING METHODS}

Conventional plant breeding involves manipulating the genes of a species so that desired genes are packaged together in the same plant and as many deleterious genes as possible are excluded. Improvements in biomass quality that can be made in species such as switchgrass is dependent upon the genetic variability for the traits of interest in the species, the heritability of the traits, the breeder's ability to identify genetically superior plants, the intensity of selection, and the efficiency of the breeding procedure. Heritability is the ratio of the genetic variation for a trait divided by the phenotypic variation.

The two main components of the plant breeding process are selection and hybridization. Selection of the plants to be mated is the critical component of the conventional breeding process since breeders evaluate phenotypes in order to select superior genotypes. The other component, hybridization or mating can usually be done in a routine manner although for some species the procedures are tedious and require a high degree of skill (Fehr and Hadley 1980, Martinez-Reyna and Vogel 1998). Breeding systems have been developed and continue to be developed that can be used to improve virtually all forage species. Recent reviews have described the relative theoretical and practical efficiencies of these systems (Sleper 1987, Vogel and Pedersen 1993). Forage breeders have an array of breeding procedures that they can use to improve forage species. The 
critical problem involved in improving forage or biomass quality is having rapid, reliable, and relatively inexpensive quality assays and relative estimates of economic value of quality traits for biomass conversion.

A few basic equations can be used to express many of the concepts involved in plant breeding (Allard 1964, Falconer 1981). Assuming selection is conducted on an individual plant basis, the heritability estimate $\left(\mathrm{h}_{\mathrm{x}}{ }^{2}\right)$ for a trait "x" (Eq. 1) is the ratio of the additive genetic variation $\left(\mathrm{F}_{\mathrm{ax}}{ }^{2}\right)$ for that trait divided by the phenotypic variance $\left(\mathrm{F}_{\mathrm{P}}{ }^{2}\right)$ (Falconer 1981). Except for a few forage species for which it is possible to produce commercial $F_{1}$ hybrids, forage breeders have to utilize additive genetic variation. Additive genetic variation is used as the numerator in Eq. 1 to provide an estimate of heritability in the narrow sense. Plant breeders and geneticists use various mating and evaluation strategies to obtain estimates of the additive genetic and phenotypic variance (Hallauer and Miranda 1981). Narrow sense heritability estimates are used to predict gain from selection and also provide an estimate of the proportion of the total variation for a trait that can be attributable to genetic differences among individuals or families. Heritability estimates can range from 1.0 for a trait such as eye color that is not affected by environment to less than 0.10 for traits that are highly influenced by environment variables.

$$
\begin{array}{lr}
\mathrm{h}_{\mathrm{x}}^{2}=\mathrm{F}_{\mathrm{ax}}{ }^{2} / \mathrm{F}_{\mathrm{P}}^{2} & \text { Eq. } 1 \\
\mathrm{G}_{\mathrm{x}}=\mathrm{i} \mathrm{h} \mathrm{h}_{\mathrm{x}} \mathrm{F}_{\mathrm{ax}} & \text { Eq. } 2 \\
\mathrm{CG}_{\mathrm{x}}=\mathrm{i} \mathrm{h} \mathrm{h}_{\mathrm{x} y} \mathrm{~F}_{\mathrm{ax}} & \text { Eq. } 3
\end{array}
$$

Gain from selection for a trait is the gain that is achieved by selecting individuals for that trait and intermating the selected plants to produce their progeny. The mean difference between the progeny of selected and unselected plants is the realized gain from selection. The expected or predicted gain from selection $\left(\mathrm{G}_{\mathrm{x}}\right)$ for trait " $\mathrm{x}$ " is the product of the standardized selection differential (i), the square root of the heritability of the trait $\left(\mathrm{h}_{\mathrm{x}}\right)$, and the square root of the additive genetic variation $\left(\mathrm{F}_{\mathrm{ax}}\right)$ (Eq. 2). The standardized selection differential is simply the proportion of selected plants expressed in units of standard deviations from the mean. The genetic gain that can be achieved in a single breeding cycle is dependent upon the relative magnitude of the factors in Eq. 2.

Selection for one trait can have an effect on another trait if the traits are genetically correlated. The expected correlated response $\left(\mathrm{CG}_{\mathrm{x}}\right)$ for trait " $\mathrm{x}$ " if selection is practiced for trait " $\mathrm{y}$ " is given in Eq. 3. The genetic correlation is $\left(\mathrm{r}_{\mathrm{xy}}\right)$. If the genetic correlation is large and the heritability for trait $\mathrm{y}$ is also large, then substantial gains from selection can be achieved for a particular trait by indirect selection for the correlated trait. Indirect selection can be as effective as direct selection if $\mathrm{h}_{\mathrm{y}}$ is $25 \%$ larger than $h_{x}$ and the genetic correlation is 0.8 or larger. Correlated responses to selection can be important in breeding for improved digestibility in terms of selection criteria. Marker assisted selection can be extremely effective if the correlation between the molecular marker (y) and the phenotypic trait $(\mathrm{x})$ is large because heritability for a molecular marker (trait $\mathrm{y}$ ) is usually 1.0 as is the additive genetic variation (see following section on marker assisted selection). When selection is practiced for a single traits such as high yield, it can have a negative effect on other traits such as lignin if the genetic correlation between yield and lignin is negative.

Plant breeders are often interested in simultaneously improving several traits. The three basic methods for improvement of more than one trait by breeding are selection indexes, independent culling, and tandem selection (Baker 1986, Wricke and Weber 1986). In tandem selection, a trait is selected until it reaches a targeted level and then breeding work is initiated on the next trait. Tandem selection is basically a trait by trait improvement method. With independent culling, minimum thresholds are established for each trait and only individuals that have all traits of interest 
above the culling level for each specific trait are selected for mating. With selection indexes, a single score is developed which is a summation of merits and demerits of an individual or family for the desired traits. It allows economic weights to be assigned to each trait of interest. Limited genetic information about the selection populations is needed for tandem selection and for independent culling. Selection indexes, however, require information on the genetic variances and covariances of the traits of interest and also relative economic weights (Baker 1986).

A selection index can be expressed as:

$$
\mathrm{I}=\mathrm{b}_{1} \mathrm{P}_{1}+\ldots \ldots .+\mathrm{b}_{\mathrm{i}} \mathrm{P}_{\mathrm{i}} \ldots \ldots \ldots+\mathrm{b}_{\mathrm{n}} \mathrm{P}_{\mathrm{n}} \quad \text { Eq. } 4
$$

where $P_{n}$ represents the observed phenotypic value of the nth trait and $b_{n}$ is the weight assigned to the trait in the selection index. The index value is an estimator of the genotypic worth or value of the a genotype. To obtain the "b" values, a set of simultaneous equations must be solved that contain the phenotypic and genetic variances and covariances of each trait and relative economic weights (Baker 1986). The phenotypic and genetic variances and covariances can be obtained from structured genetic studies. The economic weights have to be developed from economic analysis in which the relative value of specific traits to the per unit value of the final product is determined.

Developing relative economic weights for traits can range from being relatively straightforward and simple to very complex and difficult. If the traits of interest are for the same aspect of a product such as oil and protein content of soybeans, then the relative value of oil and protein in the marketplace can serve as the economic weights. It becomes more complex if two or more traits relate to different aspects of the same product. For example, increasing biomass yield of switchgrass is desirable because it can reduce the per ton production cost of feedstock. Decreasing lignin content may be desirable for increasing conversion efficiency. However, genetically decreasing lignin content may result in decreased biomass yields. This has occurred in switchgrass as the result of selection for high IVDMD. The question that has to be answered is what are the relative economic values of yield vs lignin or other quality trait. This question needs to be answered not only for the genetic improvement but also for the purchase and utilization of feedstocks at the conversion plant (see section on modifying feedstock quality using plant transformation technologies).

The stability of a trait over environments is important because it will influence the area of adaptation of an improved cultivar. Breeders can obtain estimates of the genotype $\mathrm{x}$ environment interactions by growing cultivars or experimental strains in an array of environments. Variance component analyses and regression procedures are used to determine the relative magnitude of genetic, environment, and genotype $\mathrm{x}$ environment interaction $(\mathrm{GxE})$ effects. If genetic effects are significant and $\mathrm{GxE}$ effects are nonsignificant for a specific trait even though environment effects are large, then the trait is stable over environments. If GxE effects are larger than genotypic effects, it may be necessary for breeders to develop cultivars for specific environments.

Genetic variability for forage quality traits has been found for virtually every species for which a well designed and conducted trial has been completed including forage digestibility. In most populations of herbaceous plants that have been studied, a range in IVDMD of $100 \mathrm{~g} \mathrm{~kg}^{-1}$ has often been found between individuals of the same population (Casler and Vogel 1999). Realized heritabilities have been 0.2 to 0.3 and the rate of genetic progress in breeding for improved IVDMD has ranged from 8 to $45 \mathrm{~g} \mathrm{~kg}^{-1}$ cycle $^{-1}$ ( 1.3 to $12.1 \%$ cycle $^{-1}$ or 0.7 to $2.5 \%$ year ${ }^{-1}$ ) which is similar to long-term gains for grain yield of cereal crops (Casler and Vogel 1999). Genetic variation for cell wall monosaccharides, NDF, and ADF in a lowland switchgrass population was evaluated by Godshalk et al. (1988b). Significant genetic variation was found for arabinose, galactose, glucose, xylose, hexose, pentose, and total sugars expressed as $\mathrm{g} \mathrm{kg}^{-1} \mathrm{NDF}$ and for IVDMD, NDF, and ADF. Heritability estimates as determined by parent-progeny regression were greater than 0.5 for all traits 
(Godshalk et al.1988b). IVDMD was positively correlated to glucose and hexose sugar concentrations but was negatively correlated to the other monosaccharides.

Switchgrass is one of the principal species on which breeding and genetics research has been conducted to genetically modify herbage or biomass quality. Breeding work to improve the IVDMD of switchgrass has been conducted by co-author Vogel and colleagues for over 20 years and a series of experiments have been conducted evaluating the breeding progress and associated changes in switchgrass biomass composition. This research also has lead to the release of two switchgrass cultivars, Trailblazer and Shawnee, with improved IVDMD (Vogel et al. 1991 1996).

Breeding for high IVDMD in switchgrass started in an experiment in which a switchgrass population (EY x FF) was divergently selected for IVDMD using Restricted Recurrent Phenotypic Selection (RRPS) procedures. The high and low IVDMD populations were evaluated in small trials and in subsequent grazing trials. An additional two cycles of RRPS for high IVDMD have been conducted and were used to produce High IVDMD C2 and C3 strains that have been used in several subsequent studies on the inheritance of IVDMD in switchgrass, the stability of the trait over environments, and the correlated response of agronomic traits including yield and plant survival and associated forage quality traits. These experiments demonstrated that the IVDMD of switchgrass was improved by breeding by using a form of modified mass selection with selected plants polycrossed in isolation (Vogel et al. 1981). It demonstrated that the IVDMD of switchgrass plants sampled at panicle emergence was an excellent predictor of the IVDMD of their progeny in pastures throughout the grazing season (Gabrielsen et al. 1990). A small improvement in IVDMD (3 to 4 percentage units) significantly improved animal performance (17 to 24\%) as measured by both average daily gains and beef production per hectare in a replicated grazing study conducted for three years (Anderson et al. 1988). Differences in animal performance were not due to differences in selectivity but to intrinsic differences in quality (Ward et al. 1989). Additional research demonstrated that changes in forage digestibility were achieved by increasing the extent of cell wall digestibility and not by changing the cell wall to cell solubles ratio or the rate of cell wall digestibility (Moore et al. 1993). The improvement in IVDMD was accompanied by correlated changes in the molar ratio of ferulic acid and p-coumaric acid demonstrating that these components of plant cell walls were heritable and genetically correlated with IVDMD (Gabrielsen et al. 1990). Genetic changes in IVDMD in switchgrass were demonstrated to be stable over a wide range of environments (Hopkins et al. 1995a 1995b). Estimated and realized heritability for IVDMD averaged over three cycles were 0.40 and 0.31, respectively (Hopkins et al. 1993).

Results from the research on developing switchgrass strains differing in IVDMD also has demonstrated that other herbage traits can be genetically modified. Hopkins et. al. (1995a) grew almost all adapted switchgrass cultivars and experimental strains at three Midwest locations (Mead, NE; Ames, IA, and West Lafayette, IN) and harvested biomass yields for two years. The C-1, CO, $\mathrm{C} 1$ (Trailblazer) and C3 High IVDMD strains were included in these trials. The " $\mathrm{C}$ " is for breeding cycle, the number following the $\mathrm{C}$ denotes the cycle or generations and a negative sign indicates selection for low IVDMD. Averaged over years and locations, the C3 High IVDMD strain was $45 \mathrm{~g}$ $\mathrm{kg}^{-1}$ higher in IVDMD than the CO strain and also was $8 \mathrm{~g} \mathrm{~kg}^{-1}$ lower in acid detergent lignin (ADL) (Hopkins et al. 1995a). The C3 High IVDMD strain also was $1547 \mathrm{~kg} \mathrm{ha}^{-1}$ lower in biomass yield. In other research, Fritz et al. (1991) demonstrated that there were changes in neutral sugar concentration of cell wall hydrolysates from biomass harvested from progeny of the High and Low IVDMD strains (Table 2). 
Table 2. Concentrates of neutral sugars in cell-wall hydrolysates from ammoniated switchgrass herbage harvested at heading at Lincoln, Nebraska, as affected by genetic strain averaged over ammoniation rates of $0,10,20,40 \mathrm{~g} \mathrm{~kg}^{-1}$ (from Fritz et al. 1991)

\begin{tabular}{lllll}
\hline \multirow{2}{*}{ Strain } & Arabinose & Xylose & Galactose & Glucose \\
\cline { 2 - 5 } & -1 & & \\
High IVDMD & 39.5 & 430 & 15.2 & 515 \\
Low IVDMD & 36.3 & 419 & 10.6 & 534 \\
SE & 3.0 & 8.6 & 1.0 & 3.4 \\
\hline
\end{tabular}

Selection for high IVDMD in the EY x FF switchgrass population had correlated genetic affects on other traits. Regression analysis of location means for cycles C-1 to C3 (Hopkins 1993; Hopkins et al. 1995a) indicated that for each unit change $\left(\mathrm{g} \mathrm{kg}^{-1}\right)$ in IVDMD biomass yield decreased by 27 $\mathrm{kg} \mathrm{ha}^{-1}$, crude protein increased by $0.2 \mathrm{~g} \mathrm{~kg}^{-1}$, NDF decreased by $0.21 \mathrm{~g} \mathrm{~kg}^{-1}$, and ADL decreased by $0.15 \mathrm{~g} \mathrm{~kg}^{-1}$. (Data from co-author K.Vogel). Except for the first cycle of selection that produced the cultivar Trailblazer, each cycle of advanced selection for high IVDMD also reduced digestible yield (Mg IVDMD ha-1 ${ }^{-1}$ ) and holocellulose yield (cellulose + hemicellulose yield) (Table 3 ).

Because it had biomass yield equivalent to the $\mathrm{C} 0$ and the low IVDMD C-1 population and also had improved IVDMD, Trailblazer gave higher digestible yield than these strains (Table 3).

In 1986, a cycle 4 High IVDMD RRPS selection nursery was established at Mead, Nebraska. By early summer of 1987, it was obvious that most of the plants in the nursery had winter killed. Only about 100 plants remained alive. Several studies have subsequently been conducted to evaluate the effect of breeding for high IVDMD on plant yield and survival of switchgrass. Seed was harvested from all the surviving plants and bulked to produce a High IVDMD C3 WS (winter survivor) population. This strain was included in the multistate trials summarized by Hopkins et al. (1995a). There were no significant differences between the High IVDMD C3 and 
Table 3. Mean biomass yield, IVDMD, digestible yield, and holocellulose yield for switchgrass strains grown at three midwest locations and harvested at heading which were selected for IVDMD or yield and IVDMD ${ }^{a}$

\begin{tabular}{|c|c|c|c|c|}
\hline \multirow[t]{2}{*}{ Strain } & \multirow[t]{2}{*}{ IVDMD } & \multicolumn{3}{|c|}{ Yield } \\
\hline & & Biomass & Digestible & Holocellulose \\
\hline & $\mathrm{g} \mathrm{kg}^{-1}$ & $\mathrm{~kg} \mathrm{ha}^{-1}$ & $\mathrm{~kg} \mathrm{ha}^{-1}$ & $\mathrm{~kg} \mathrm{ha}^{-1}$ \\
\hline Cave-in-rock & 434 & 13866 & 6045 & 9550 \\
\hline Shawnee & 446 & 13709 & 6143 & 9441 \\
\hline \multicolumn{5}{|l|}{ EY x FF strains: } \\
\hline $\mathrm{C}-1$ & 398 & 11904 & 4715 & 8373 \\
\hline $\mathrm{C} 0$ & 427 & 11366 & 4830 & 7959 \\
\hline Trailblazer & 429 & 11851 & 5085 & 8296 \\
\hline $\mathrm{C} 3$ & 473 & 9818 & 4644 & 6859 \\
\hline $\mathrm{SE}^{a}$ & 6 & 367 & 161 & 242 \\
\hline
\end{tabular}

${ }^{a}$ Digestible yield $=$ IVDMD\% $x$ Biomass yield; Holocellulose yield $=($ NDF \% - ADL \% $) \times$ Biomass yield. SE $=$ standard error of the mean.

High IVDMD C3 WS strains for any of the traits evaluated including IVDMD and ADL. Significant stand loss did not occur in any of these nurseries, but since the plots were solid seeded, loss of plants could have been compensated by tillering of adjacent surviving plants.

Two subsequent space-transplanted studies were initiated to determine the effect of breeding for increased IVDMD or associated cell wall traits on plant yield and survival. Both studies have been recently summarized and are unpublished to date. In a cooperative study, co-author Vogel, M. Casler (University of Wisconsin-Madison) and D. Buxton (USDA-ARS, Ames, Iowa) evaluated populations of four perennial herbaceous species (switchgrass, orchardgrass, bromegrass, and alfalfa) that were genetically modified for altered lignin content or associated forage digestibility by conventional plant breeding. The strains were evaluated for fitness in three midwest USA environments (Mead, Nebraska; Ames, Iowa; and Madison, Wisconsin) for over four years (Casler et al. 2000). The EY x FF low and high IVDMD strains were included in these trials. The results from this research clearly demonstrate that breeding for increased IVDMD or decreased lignin concentration significantly altered both traits over breeding cycles (Fig. 3). Results also clearly demonstrate that for two of the species, switchgrass and orchardgrass, significant associated changes in plant survival and/or biomass yield occurred (Fig. 4). 


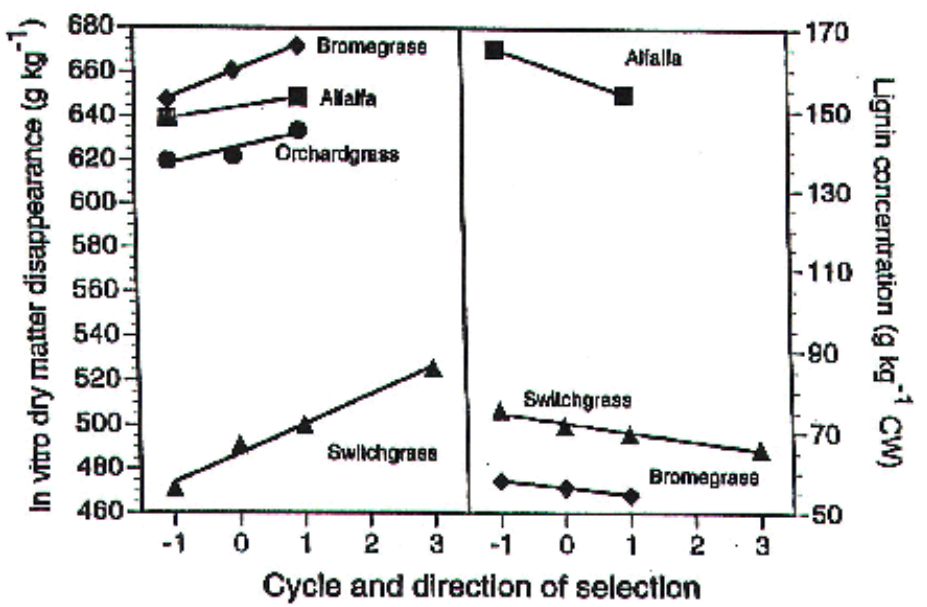

Fig. 3. Divergent phenotypes of populations selected for different levels of in vitro dry matter disappearance of lignin concentration (expressed as a proportion of the cell wall, CW). Eacy cycle of selection represents identification of parents with either high $(+1)$ or low (! 1) in vitro dry matter disappearance, followed by intercrossing and evaluation of progeny. Cycle 0 represents the original population. All responses were linear with $\mathrm{P}<0.05$. Alfalfa data are means over three environments (14), bromegrass data are means over four environments (15), orchardgrass data are means over give environments (16), and switchgrass data are means over eight environments (17). Lignin data were not available for the orchardgrass populations. The cycle 2 high-IVDMD switchgrass selection was not available for evaluation.

Seed was harvested from the original High IVDMD C3 parent clones in the C3 polycross nursery and was used to produce half-sib family seedlings that were planted into a replicated $(\mathrm{r}=3)$ half-sib progeny nursery in 1991 at Mead, Nebraska. Half-sib family plots were single rows of plants spaced $1.1 \mathrm{~m}$ apart. Transplanted seedlings were used in this study as in the Casler et al.(2000) study described above to ensure initial stands. The nursery was harvested in 1993 and 1995 for biomass yield after plants had headed. Forage from the harvested plots were analyzed for IVDMD. Stand counts were made in late summer of 1993 and 1995. The 1995 stands were used to determine survival percentage. In addition to the 49 half-sib families, check strains EY x FF Low IVDMD C-1, Trailblazer (EY x FF High IVDMD C1) and the EY x FF High IVDMD C3 parent bulk population were included in the trial. There were significant differences among the families for biomass yield, IVDMD, and plant survival (Table 4). Among the half-sib families, the correlations were: IVDMD and yield, $\mathrm{r}=! 0.35^{* *}$; yield and survival $\%, \mathrm{r}=0.19$; IVDMD and survival $\%, \mathrm{r}=$ 0.03 . (*,** indicate statistical significance at the 0.01 and 0.05 levels of probability, respectively).

These results indicate that there is genetic variation for plant survival in the high IVDMD C3 population and that it should be feasible to continue to breed for high IVDMD in this switchgrass population, but plant survival over years needs to be monitored. This will require multiyear evaluation nurseries. 

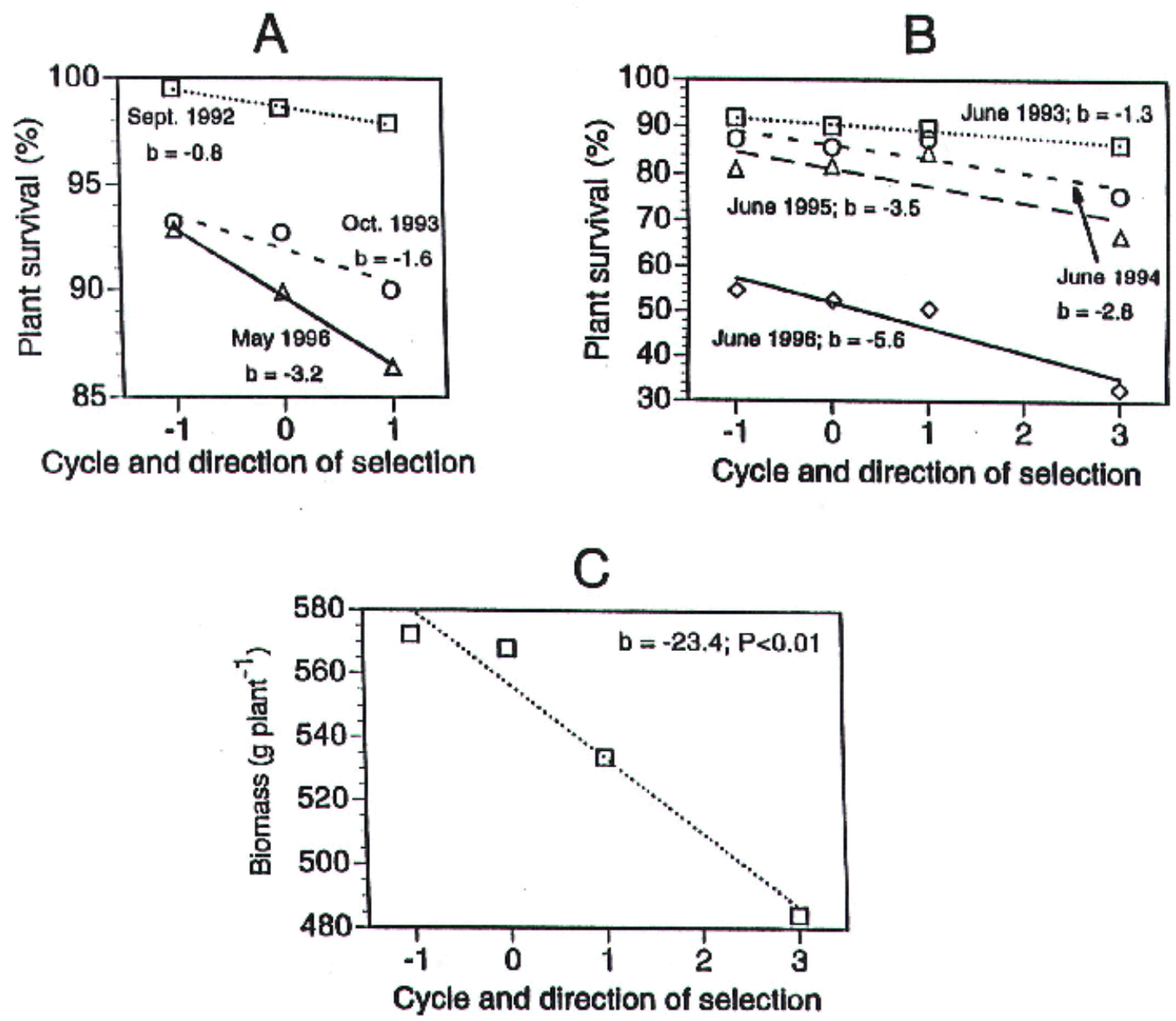

Fig. 4. Fitness of divergent-IVDMD selections. Each cycle of selection represents identification of parents with either high (+1) or low(! 1) IVDMD, followed by intercrossing and evaluation of progeny. Cycle 0 represents the original population. All responses were linear with $\mathrm{P}<0.05$. Each data point represents a mean over four replicates and three locations (18). (A) Survival of orchardgrass transplants at three sampling dates. approximately 4, 17, and 48 months after transplanting. (B) Survival of switchgrass transplants at four sampling dates, approximately $12,24,36$, and 48 months after transplantiing. (C) Aboveground biomass of switchgrass transplants (means over 2 years). 
Table 4. Multiyear means and range values for herbage yield, herbage in vitro dry matter digestibility, and survival percentages for half-sib progeny of EY x FF High IVDMD C3 switchgrass parent plants and the check populations, EY x FF Low IVDMD C-1, Trailblazer, and EY x FF High IVDMD C3 parent bulk population

\begin{tabular}{|c|c|c|c|}
\hline Strains & $\begin{array}{c}\text { Herbage yield } \\
\text { kg plant }^{-1}\end{array}$ & $\begin{array}{r}\text { IVDMD } \\
\mathrm{g} \mathrm{kg}^{-1}\end{array}$ & $\begin{array}{c}\text { Plant survival } \\
\% \\
\end{array}$ \\
\hline EY x FF Low IVDMD C1 & 0.72 & 514 & 68 \\
\hline Trailblazer & 0.69 & 520 & 76 \\
\hline EY x FF High IVDMD C3 & 0.69 & 548 & 54 \\
\hline \multicolumn{4}{|c|}{$\begin{array}{l}\text { EY x FF High IVDMD C } 3 \text { half-sib } \\
\text { progeny }(n=49)\end{array}$} \\
\hline Mean & 0.54 & 543 & 49 \\
\hline Range & 0.33 to 0.90 & 520 to 567 & 19 to 88 \\
\hline \multicolumn{4}{|l|}{ Example half-sib families: } \\
\hline 519 & 0.42 & 525 & 19 \\
\hline 409 & 0.53 & 532 & 38 \\
\hline 511 & 0.59 & 538 & 88 \\
\hline 708 & 0.56 & 559 & 46 \\
\hline 1228 & 0.53 & 547 & 71 \\
\hline F or Entries & $1.92^{a}$ & $2.34^{a}$ & $2.14^{a}$ \\
\hline LSD 0.05 & 0.15 & 19 & 21 \\
\hline
\end{tabular}

${ }^{a}$ Indicates statistical significance at the 0.01 level of probability.

Direct selection in forages for cell wall components has been conducted less frequently than for IVDMD or NDF concentration. Alfalfa was selected for low and high ADL concentrations (Hill 1981), but because selection was imposed on total herbage the observed changes in ADL were primarily caused by shifts in leaf-to-stem ratio between the low and high ADL selection lines (Kephart et al. 1989 1990). Selection in corn or maize (Zea mays L.) vegetative tissue for divergent concentrations of ADF resulted in genetic alteration of NDF, ADF, and ADL concentrations for both leaf sheath and stem tissues (Buendgen et al. 1990). Cellulose concentration was elevated in both leaf sheath and stem tissues of the high ADF line, but hemicellulose concentration was only greater in stem tissue. In another study on maize, Ostrander and Coors (1997) demonstrated that selection for high NDF, ADF, and lignin increased those traits while selection for low traits decreased those traits. Selection for improved forage yield and quality has coincidentally generated a bermudagrass (Cynodon dactylon (L.) Pers.) cultivar (Tifton 85) with increased concentration of cellulose (Mandebvu et al. 1999). 
Selection for cell wall composition also has been conducted on cool-season grasses. Casler and Jung (1999) attempted to select smooth bromegrass (Bromus inermis Leyss.) for divergent concentrations of Klason lignin and ferulate cross-linking of lignin to arabinoxylan in young leaves. Selection for Klason lignin was unsuccessful, probably due to large environmental variation, but high and low ferulate cross-linking genotypes were identified. Reduced ferulate mediated cross-linking resulted in improved in vitro NDF digestibility with rumen microrganisms (Casler and Jung 1999). In bromegrass, Casler demonstrated that selection for reduced NDF using six different breeding procedures resulted in increased IVDMD (Casler 1999 a,b,c). When selection for reduced NDF was based on forage collected at heading, correlated responses included a $0.15 \mathrm{Mg} \mathrm{ha}^{-1}$ cycle $^{-1}$ reduction in biomass yield, a 7.5\% per cycle reduction in stem tissue with a concommitant increase in leaf and sheath components, and reduced stem and sheath NDF (Casler 1999a,b,c). Surprenant et al.(1988) used independent culling in reed canarygrass (Phalaris arundinaceae L.) populations in which plants were selected first for high or low NDF and then for high or low yield. Progeny populations produced by the divergent sxelection and intermating differed significantly for NDF, $\mathrm{ADF}$, and crude protein. Within a fiber selection group, the populations selected for high yield had significantly higher forage yields on a per plant basis than those selected for low yield. Reed canarygrass populations selected for low NDF had lower yields than the base population even when selection included selection for high yield (Surprenant et al. 1988). All the research that has been completed to date on both cool- and warm-season grasses on IVDMD, NDF, ADF, and ADL indicates that these traits are relatively stable over environments (Casler and Vogel 1999).

The effectiveness of selection indexes in improving yield and IVDMD were evaluated by Godshalk et al. (1988a) in a study in which they compared the results of three different selection indexes for improving yield and IVDMD of switchgrass. Indexes were (1) for increased yield with IVDMD and $\mathrm{N}$ (nitrogen concentration) as covariates, (2) increased yield and IVDMD with $\mathrm{N}$ as a covariate, and (3) increased IVDMD with yield and $\mathrm{N}$ as covariates. Covariates had a weight of zero. Out of a low-land switchgrass source population of 660 plants, 3-16 plant polycross populations were produced with plants selected using each index. Seed from the polycross populations was used to establish a replicated space planted evaluation nursery near Clayton, North Carolina. Cycle 0 or base population plants were included in the nursery to serve as a reference base. Index 1 resulted in increased yield, increased NDF and ADF but decreased IVDMD. Index 2 increased yield and resulted in nonsignificant changes in NDF, ADF, and IxVDMD. Yield improvement was less than for Index 1. Index 3 resulted in a decrease in yield, decrease in NDF and ADF and an increase in IVDMD. Gains in IVDMD were achieved but only with associated loses in yield. Economic weights were not used in developing the indexes.

These results were predictive of selection for high IVDMD in the Agricultural Research Service, USDA and University of Nebraska (NE-ARS) EY x FF switchgrass population.

In the NE-ARS program, however, selection for high yield and high IVDMD has been practiced using a selection index that weights both traits equally. This index was used to develop the cultivar Shawnee. Shawnee has biomass yields equivalent to the parent population, the cultivar Cave-inRock, but has higher IVDMD which results in higher digestible yield per acre (Table 3). These results and the results achieved by generations of breeding for high yield and high IVDMD in bermudagrass as summarized by Vogel and Sleper (1994) demonstrate that it should be feasible to improve both yield and quality traits in herbaceous plants. In the future, the most effective methods to improve both yield and quality traits using conventional breeding methods will involve the use of selection indexes in which molecular markers (see following section), conventional quantitative data, and economic weights are used. However, to be most effective in modifying herbaceous plants for conversion to liquid fuels, quality factors affecting cxonversion to liquid fuels need to be identified and economic weights assigned to them in relationship to biomass yield.

Lignin is present in all terrestrial higher plants including herbaceous perennials. It is involved in structural support, anti-herbivory, and wound response. Lignin concentration and composition in 
herbaceous perennials was previously believed to affect evolutionary fitness via xits inhibition of herbivory. The switchgrass results clearly demonstrate that lignin may also be involved in the plant's ability to survive in the absence of herbivores. These results also indicate that perennial plants genetically engineered with altered lignin concentration or composition for use in livestock, pulp and paper, or bioenergy production will need to be evaluated for fitness prior to use in agriculture. It also points out the need to monitor the effect of changing other plant composition traits on plant survival and biomass yield and the importance of having relative economic value of quality traits.

\section{UTILIZATION OF GENETIC MARKERS TO ENHANCE PLANT BREEDING EFFECTIVENESS}

Plant breeders using conventional plant breeding methods evaluate phenotypes. A phenotype is the product of the genotype of a plant as it is modified by the environment in which it is grown. Heritability estimates provide an indication of the magnitude of the environmental effect for a particular trait. For many important traits such as yield or IVDMD that are the result of the actions of many genes, heritabilities are usually 0.30 or lower which indicates that only $30 \%$ of the total phenotypic variation that is measured is due to genetic differences among individuals. The efficiency of plant breeding could be greatly enhanced if breeders could directly measure or identify genotypes. Molecular markers can provide breeders with the ability to identify desired alleles or quantitative trait loci (Brummer 1998). Molecular markers are currently being used or their use is being evaluated in most of the major grain crops and some initial work has been done in some forage crops such as alfalfa and tall fescue (Festuca arundinaceae Schreb.) (Brummer 1998). The rapidly developing field of genomics includes the use of molecular markers and involves an array of sophisticated and expensive technologies (Liu 1998). Knapp (1998) recently presented theory for estimating the probability of selecting one or more superior genotypes by using marker assisted selection (MAS) and then used this information to estimate the cost efficiency of marker assisted selection relative to conventional phenotypic selection. His results indicate that MAS substantially decreases the resources needed to accomplish a selection goal for a low to moderately heritable trait when the selection goal and the selection intensity are high.

In a recent view, Sleper and Chen (1998) describes the molecular marker tools that can be used in forage grasses including RFLPs, RAPD (Random Amplified Polymorphic DNA), Variable Number Random Repeats (mini-satellites and micro-satellites), and AFLPs (Amplified Fragment Length Polymorphism). All methods have advantages and disadvantages. To date in switchgrass, a chloroplast RFLP marker has been identified that can be used to differentiate lowland and upland ecotypes (Hultquist et. al. 1996 ) and Gunter et al. (1996) used a set of RAPD markers to evaluate genetic relationships among released switchgrass cultivars and experimental stains. A molecular map for switchgrass has not been developed to date. The Herbaceous Energy Crops Program, Oak Ridge National Laboratory is funding research at the Oak Ridge National Laboratory and the University of Georgia to develop a molecular map for switchgrass based on simple sequence repeats (SSR) (Personal communication, J. Bouton and L. Gunter with co-author, K. Vogel 1999).

Research would then have to be conducted to link molecular markers to genes controlling bioenergy traits in switchgrass.

Identification of quantitative trait loci (QTLs) for use in marker assisted selection has only just begun for cell-wall traits. A series of QTLs were identified for ADF (presumed to consist of cellulose, lignin, cutin, and ash) in whole corn plants harvested at silage maturity (Lubberstedt et al. 1997). Unfortunately, the authors only reported QTL data for a calculated forage quality trait (metabolizable energy content, MEC) derived from ADF. These two traits were highly correlated ${ }^{\circledR}$ $=! 0.98$ ) and, according to the authors, gave "almost identical results in QTL analyses" 
(Lubberstedt et al. 1997). Over two experiments, 15 QTLs for MEC were found spread over nine of the 10 corn chromosomes with very little overlap of QTLs between experiments. The individual QTLs accounted for 3 to $10 \%$ of the variation in MEC and in combination these QTLs accounted for 16 and $24 \%$ of the variation in MEC in the two experiments.

A second QTL study has been done in corn where the components of the cell wall (individual neutral sugars, uronic acids, lignin concentration and composition, and ester- and ether-linked hydroxycinnamic acids) were examined (Ni, Jung, and Phillips, unpublished). In a preliminary report (Ni et al. 1998), five to 15 QTLs were identified for each lignification trait (except lignin concentration for which no significant QTLs were found) and in combination these QTLs accounted for 52 to $96 \%$ of the phenotypic variation. For the polysaccharide components, seven to 15 QTLs were found for each sugar residue and these accounted for 73 to $94 \%$ of the variation in combination. Twenty percent of the polysaccharide component QTLs were found on chromosome five and several QTLs were shared by both polysaccharide and lignification traits. These overlapping QTLs may be involved in coordinated deposition of the various polymers comprising the cell wall (Ni et al. 1998).

The only other marker research concerning cell-wall traits of which we are aware is an international project. Working with barley, pearl millet, perennial ryegrass, and Brachiaria to improve their digestibility by livestock, several international centers in the CGIR network and the Australian Center for International Agricultural Research are searching for QTLs for a variety of cell wall traits. No results from this project have been published to date. Plants from the High IVDMD and low IVDMD populations developed by the USDA-ARS breeding program at Lincoln, Nebraska, could be used to identify QTLs that control this complex trait in switchgrass and also identify QTLs affecting winter survival.

Development of a molecular map for switchgrass and other potential herbaceous biomass species and associated markers is needed for use in marker assisted selection. Molecular makers also are needed to monitor gene flow from domesticated switchgrass fields to wild populations. Research to date indicates that genes and their structural organization within genomes of Gramineae have a high degree of similarity (Stuber et al. 1999). Comparative maps and mapping information from other species should be very useful in developing markers for marker assisted selection in switchgrass. In addition, significant advances are being made in understanding the genetic control of cell wall synthesis in model species such as Arabidopsis (Arabidopsis thaliana (L.) Heynh.) which should enable specific genes to be targeted in marker assisted selection. 


\section{MODIFYING SWITCHGRASS QUALITY USING PLANT TRANSFORMATION TECHNOLOGIES}

Genes that are available for plant breeders to manipulate using conventional breeding methods are those that a species has accumulated during its evolutionary history. Until very recently, the only genes that were available to a breeder for improving a species in a conventional breeding program were the genes that were in the plants of a species or its close relatives. Genes can be moved between plants of closely related species with varying degrees of difficulty. Moving genes between unrelated species is not possible using conventional breeding methods. Molecular genetic approaches have and are making it possible to clone genes from virtually any living organism and insert the cloned gene into another organism including forage plants. The transformed plants express the cloned genes and produce the gene products of the inserted gene. Molecular genetics and transformation procedures give plant breeders the potential to use genes from any organism to improve a plant species.

Conger (1998) recently reviewed transformation research on forages. Genetic transformation has been reported in several forage grasses including orchardgrass, tall fescue, red fescue (F. rubra L.), meadow fescue ( $F$. pratensis Huds), perennial ryegrass, creeping bentgrass, and redtop. In forages grasses, transformation has been accomplished by direct uptake of DNA by protoplasts or by microprojectile bombardment. Proof of the transformation has been by PCR techniques, Northern hybridization analysis of transcribed DNA, western blot analysis of soluble protein gene products, and Southern blot hybridization of total genomic DNA. Alfalfa and other legumes also have been transformed. The most effective transformation method for dicots has been via Agrobacterium tumefaciens transformation procedures. Until recently this procedure was not effective for Gramineae because of their resistance to Agrobacterium. There have been recent reports of Agrobacterium mediated transformation of rice and maize (Conger 1998, Ye 2000). The particle bombardment or gene gun technology was a major advance in the transformation of monocots. There are several different types but all appear to be effective if good protocols are development. An effective transformation system requires a gene deliver system (gene gun or Agrobacterium), appropriate tissue and regeneration systems (embryonic calls cells or suspension culture cells), desirable genes, promoters genes, and selectable marker genes. All components are now available for transformation of forage grasses. To date the genes of most interest have been for herbicide and insect resistance, but genes for modifying forage quality are also of interest.

Plant transformation technologies for switchgrass are being developed by Dr. Bob Conger and his associates at the University of Tennessee with support by the Bioenergy Feedstock Development Program, Oak Ridge National Laboratory. This research effort was initiated in 1992, and since that time efficient and repeatable methods for regenerating switchgrass plants from in vitro cultured cells and tissues have been developed (Denchev and Conger 1994; Alexandrova et al. 1996 $\mathrm{a}, \mathrm{b}$ ) including the recent development of a method for regenerating switchgrass plants from cells in suspension culture (Dutta and Conger 1999). A nursery with 1000 regenerated plant has been established at the University of Tennessee (Conger et. al. 1999). Conger recently has transformed switchgrass by bombarding switchgrass cells with tungsten particles coated with plasmids psGFPBar and pAHC25 and has achieved expression of both green fluorescent protein (gfp) and iadA which codes for the GUS (beta-glucuronidase) (Personal communication with B. Conger, Oct. 15, 1999; Conger et al. 1999). Punitively transformed switchgrass plants $\left(\mathrm{T}_{0}\right.$ generation) are currently growing in a University of Tennessee greenhouse. The transformed plants will need to be advanced several generations to ensure that the transformations are stable. Although improvements in the technology will undoubtably be made, Conger and his associates have developed the basic technology to employ transformation as a breeding procedure in switchgrass.

Conger (1998) and others have pointed out that release of transgenic forage plants could have environmental effects since many forage plants have wild relatives. Traditionally most of the traits 
in plants modified by plant breeders including dwarfing, absence of dormancy, nonshattering seed, and uniform maturity have an adaptive disadvantage in the wild. Some traits for which plants could be transformed could have an adaptive advantage in the wild including resistance to biotic and abiotic stresses. It is possible that these genes could be transferred to wild relatives via sexual hybridization. Presence of such genes in wild relatives could have undesirable economic and environmental consequences (see section on environment and ecosystem constraints on the use of genetically modified organisms).

\section{Potential Targets for Molecular Manipulation}

In a 1994 review on plant cell walls it was concluded that for cell-wall polysaccharides "not a single biosynthetic enzyme has been purified to homogenity and not a single gene for any such enzyme has been cloned" (Reiter 1994). In the ensuing five years this situation has changed dramatically for cellulose biosynthesis (Delmer 1999), but only minimal progress has been achieved for hemicellulose or pectin synthesis. In contrast, the molecular biology of lignification has progressed to the point where virtually every enzyme for monolignol synthesis has been cloned and many research groups are actively producing and evaluating transgenic plants (Baucher et al. 1998). The following discussion will cover current knowledge of the biosynthetic pathways, genes isolated to date, and reported results with transgenic plants for the cell-wall polymers.

\section{Lignin}

Lignin is synthesized from monolignols produced in the shikimic acid pathway (Fig. 5).

Baucher et al. (1998) provide an excellent current review of the biochemistry and molecular biology of lignification. The monolignol biosynthesis pathway has been described as a web because of the many possible routes of synthesis (Sewalt et al. 1997). More recently Chiang and co-workers (Osakabe et al. 1999, Li et al. 1999, Li et al. 2000) have proposed that the major flux of lignin biosynthesis passes through caffeic acid to caffeoyl-CoA to feruloyl-CoA, and then to coniferyaldehyde. This route bypasses ferulic and sinapic acids as lignin precursors. Conversion to sinapyaldehyde occurs at the aldehyde level in this modified biosynthetic pathway (Osakabe et al. 1999; Li et al. 1999; Li et al. 2000). A unique aspect of lignin biosynthesis is that the polymerization reaction occurs as a free radical reaction of monolignols outside the cell's cytoplasm in the cell wall. Only a single gene for an enzyme in the monolignol pathway ( $p$-coumaric acid 3hydroxylase) has not been cloned. All the other genes have been cloned, usually from numerous plant species, and generally multiple copies of each gene have been cloned from individual species. While monolignol synthesis has been well characterized, how the monolignols are transported to the cell wall for polymerization is still unclear (Reiter 1994). The enzyme (peroxidase and/or laccase) responsible for monolignol polymerization has yet to be determined. In grasses, ferulate esters of arabinoxylans appear to serve as nucleation sites for lignin polymerization (Ralph et al. 1995), although mutant corn plants selected for reduced concentrations of ferulate esters in seedling leaves were shown to deposit normal amounts of lignin in the wall (Jung et al. 1999a). While ferulates act as lignin/polysaccharide cross-linking agents in the Gramineae, similar cross-linking structures have not been identified in other plant groups. 
Pl Phe $\stackrel{\text { PAL }}{\rightarrow}$

Cinnamic acld<smiles>O=C(O)/C=C/c1ccc(O)cc1</smiles><smiles>O=C(O)/C=C/c1ccc(O)c(O)c1</smiles><smiles>[CH-]C</smiles><smiles>COc1cc(/C=C/C(=O)O)ccc1O</smiles><smiles>COc1cc(/C=C/C(=O)O)cc(OCCOc2cc(/C=C/C(=O)O)cc(O)c2O)c1O</smiles>

p-Coumarie acld Cafralc acid H 5.Hydroxyterulle acld sinaple acld $\downarrow 4 \mathrm{CL}$

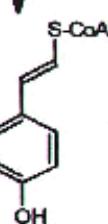

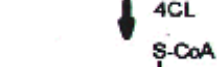

Ferulle ncld

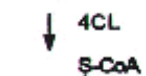

$\downarrow 4 \mathrm{CL}$

$\underset{\rightarrow}{\operatorname{CCOA} 3 H}$

s.cos

$+{ }_{\mathrm{S}-\mathrm{COA}}^{\mathrm{CL}}$

COAOMT

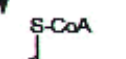

$\operatorname{sic} A$

$\mathrm{OH}$

-Coumaryl-CoA

$\downarrow \mathrm{CCR}$<smiles>O=CC=Cc1ccc(O)cc1</smiles>

OH

p-Coumaryaldehyde

$\downarrow C A D$

$\mathrm{CH}_{2} \mathrm{OH}$<smiles>CC=Cc1ccc(O)cc1</smiles>

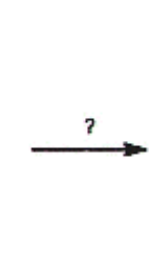

Calfeoyl-CoA<smiles>c1ccc2ccccc2c1</smiles>

$\mathrm{OOH}_{3} \mathrm{HO}_{\mathrm{O}}$

COAOMT?

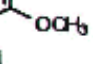

Feruloyt.CoA 5-Hydroxyteruloyt-CoA 8Inapoyl-CoA

$\checkmark \mathrm{CCR} \downarrow \mathrm{CCR} \downarrow \mathrm{CCR}$

$\checkmark \mathrm{CCR}$

$\int^{\text {CHO }}$

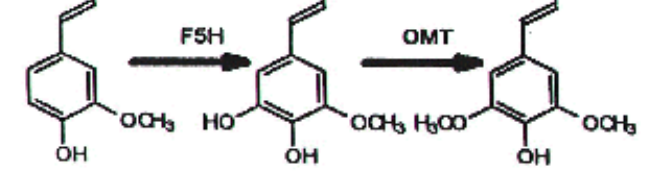

Conifaryaldahyde s-Hydroxyconlfaryaldehydn BInapyaldehyda

CAD $\quad$ CAD

p-Coumaryl alcohol

$\downarrow$ Peroxidas

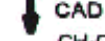

$\mathrm{CH}_{2} \mathrm{OH}$

p-Hydroxyphenol llgnin

the lignin biosynthetic pathway starting from phenylalanine (Phe). Tyrosine is the second precursor to this pathway via tyrosine ammonia lyase to form $p$-coumaric acid. The enzymes involved in lignin synthesis include: PAL, phenylalanine ammonia lyase; $\mathrm{C} 4 \mathrm{H}$, cinnamate 4-hydroxylase; $\mathrm{C} 3 \mathrm{H}$, 4-coumaroyl hydroxylase; OMT, $O$-methyltransferase; $\mathrm{F} 5 \mathrm{H}$, ferulate 5hydroxylase; 4CL, 4-coumarate-CoA ligase; CCoA3H, 4-coumaroyl-CoA hydroxylase; CoAOMT, caffeoyl-CoA $O$-methyltransferase; CCR, cinnamoyl-CoA reductase; CAD, cinnamyl alcohol dehydrogenase, and peroxidase. The bold arrows indicate the major route of lignin synthesis as proposed by Chiang and co-workers (Osakabe et al. 1999; Li et al. 1999; Li et al. 2000). 
The brown midrib (bmr) mutants of annual $\mathrm{C} 4$ grasses (maize, sorghum, and pearl millet [Pennisetum glacum (L.) R.Br.]) have served as models for scientists interested in modifying lignification through biotechnology. Four spontaneous $b m r$ mutants have been identified in corn and the mutated genes are on different chromosomes (Neuffer et al. 1968). The specific genes affected in these $b m r$ mutants has been determined for two of the mutants ( $b m r 3$ and $b m r l)$. Two independent mutations have been identified in the $O$-methyltransferase $(O M T)$ gene of $b m r 3$ maize (Vignols et al. 1995). This enzyme catalyzes the methylation of the 3- and 5-position hydroxyl groups on the aromatic ring structures of caffeic and 5-hydroxyferulic acids, respectively, in monolignol synthesis. The net result of the bmr3 mutation is a reduction in both the total amount of lignin deposited in the cell wall and a shift in lignin composition away from syringyl-type lignin because conversion of 5-hydroxylferulate to sinapate is required for syringyl lignin synthesis. Recently bmrl corn was shown to be caused by a mutation in the cinnamyl alcohol dehydrogenase gene (CAD, Halpin et al. 1998). The CAD enzyme converts cinnamyl aldehydes to their alcohol derivatives in the last step of monolignol synthesis. The $b m r l$ mutation also reduces lignin concentration, but not as severely as bmr3. A spontaneous $C A D$ mutant in loblolly pine (Pinus tneda L.)has been described in which CAD enzyme activity is almost completely absent, but lignin concentration is only nominally affected (MacKay et al. 1997). This pine mutant incorporated cinnamyl aldehyde units, as would be predicted from reduced CAD activity, in addition to the normal alcohol monolignols (Ralph et al. 1997). The genes affected in the $b m r 2$ and $b m r 4$ maize mutants have not yet been identified.

Biotechnologists have created antisense and sense-suppressed transgenic tobacco (Nicotiana tabacum L.) for both the $O M T$ and $C A D$ genes (Baucher et al. 1998). Ni et al. (1994) found 15 to $57 \%$ reductions in lignin concentration due to an antisense alfalfa OMT transgene, but surprisingly lignin composition (syringyl-to-guaiacyl ratio) was not altered. Because the OMT enzyme is involved in syringyl lignin precursor synthesis, a change in lignin composition would be expected. In contrast, when an aspen (Populus tremuloides Michx.) antisense OMT transgene was inserted into tobacco, lignin concentration was not affected while lignin composition did shift to a reduced syringyl lignin content (Dwivedi et al. 1994). Use of the tobacco antisense OMT cDNA in tobacco resulted in a drastic reduction in syringyl lignin content with no change in lignin concentration (Atanassova et al. 1995). The causes for these inconsistent results are not known. Results for $C A D$ transgenic plants with reduced enzyme activity have been more consistent with all reports to date indicating no change in lignin concentration compared to normal tobacco plants, but alterations have always been observed in lignin composition (Hibino et al. 1995, Stewart et al. 1997, Yahiaoui et al. 1998).

In addition to $O M T$ and $C A D$ transgenics, the genes for phenylalanine ammonia-lyase, cinnamic acid 4-hydroxylase, caffeoyl-CoA $O$-methyltransferase, cinnamoyl-CoA reductase, and peroxidase have all been used to transform tobacco (Baucher et al. 1998). As with the $O M T$ and $C A D$ genes, in some cases lignin concentration and/or composition were altered by these other transgenes whereas in other cases little response was noted. Because of the complexity of the monolignol biosynthetic pathway, prediction of plant phenotype of transgenic plants has been difficult. As Ralph et al. (1998b) showed, transgenic plants can make lignin from a variety of monolignol precursor molecules that result in nontypical but apparently functional lignin polymers.

Surprisingly, there have been no reports for transgenic maize, or other grasses, with regard to the lignification genes. Given the availability of DNA sequences for these genes, it must be assumed that plant biotechnology companies are creating and evaluating such transgenics. Data have been reported for transgenic hybrid poplar trees (Baucher et al. 1998) and the Noble Foundation is working on transgenic alfalfa (Sewalt et al. 1996). The primary practical goals of these research efforts are to develop forage crops that have more digestible cell walls for animal feeding and trees that have improved pulping characteristics for paper production. Several reports on lignin transgenic plants have noted abnormal growth and developmental characteristics (Lee et al. 1997, Piquemal et al. 1998, Ralph et al. 1998b, Tamagnone et al. 1998). In a recent commentary on genetic 
modification of lignification, Jung and $\mathrm{Ni}$ (1998) concluded that when transgenic plants exhibited significant reductions in lignin content some abnormal growth and development were observed. These results are consistent with the reduced winter survival of the High IVDMD C3 switchgrass progeny discussed previously. The abnormal growth has generally been associated with a weakened vascular system caused by collapsed vessels (Lee et al. 1997). However, Hu et al. (1999) have now reported that antisense down regulation of the 4-coumarate-CoA ligase gene in aspen reduced lignin deposition by $45 \%$ without any detrimental impact on growth. This positive result for reduced lignin concentration in aspen is in contrast to previous reports for other lignification genes in herbaceous plants. Perhaps the very high cell wall and lignin concentrations in trees allow greater tolerance of lignin reductions. The requirement for lignin in vessel development is logical given that the first water transport tissue (protoxylem) lignifies long before adjacent tissues complete their elongation or begin to lignify (Engels and Jung 1998). In contrast, even extreme alterations in lignin composition, such as the fahl mutant of Arabidopsis which produces no syringyl lignin whatsoever (Chapple et al. 1992), do not affect plant growth. Jung and Ni (1998) hypothesized that lignin quantity may play a more important role in plant growth than lignin composition and structure. Because of the importance of lignin to plant development, one of the authors of this review (HGJ) is engaged in a project to clone the gene for synthesis of the feruloylarabinoxylan ester in corn as a way to reduce cross-linking of lignin to cell-wall polysaccharides, and thereby increase cell-wall digestibility, without reducing lignin concentration (Ni et al. 1997; Jung et al. 1999a).

\section{Cellulose}

Unlike lignin polymerization which occurs in the cell wall, cellulose is synthesized at the plasma membrane by rosette-shaped complexes (Reiter 1994). Each plant cellulose microfibril contains 36 $\$-1,4$ glucan chains, requiring that synthesis of glucan chains by the multiple units comprising each rosette complex be highly synchronized (Delmer 1999). UDP-glucose is the substrate for cellulose synthesis, but the basic repeating unit of cellulose is the dimer cellobiose and confusion remains as to how the $180^{\circ}$ shift in orientation of adjacent glucose residues in cellulose is achieved. The cellulose of higher plants is predominately in the I\$ allomorph form. Crystallization of cellulose occurs through H-bonding of glucose residues and van der Walls forces between adjacent glucan chains.

Several mutations in cellulose deposition have been identified. "Brittle" mutants exhibiting reduced mechanical strength of culms have been described in barley (Hordeum vulgare L.), maize, and rice (Oryza sativa L.) (Reiter 1994). The barley "brittle" mutant was shown to have reduced cellulose concentration and this decrease in cellulose was due to a reduction in the number of cellulose molecules rather than a decreased degree of cellulose polymerization (Kokubo et al. 1989, 1991). An Arabidopsis mutant ( $t b r$ ) has been identified that exhibits reduced deposition of highlyordered cellulose in secondary walls of specific tissues (Potikha and Delmer 1995). Three mutants (irx 1-3) that cause collapse of xylem cells in Arabidopsis stems were found in a mutagenized population (Turner and Somerville 1997). The irx3 mutant has been shown to contain reduced cellulose content (Taylor et al. 1998). The rsw-1 Arabidopsis mutant produces a less crystalline cellulose at the same time total cellulose deposition is reduced (Arioli et al. 1998). This particular mutation is expressed during primary cell wall development under high growth temperatures, and causes the rosette structures associated with cellulose synthesis to disintegrate. It appears that the irx3 mutant is specific for secondary wall cellulose synthesis whereas the $r s w-1$ mutant is localized to the primary wall (Taylor et al. 1999).

In contrast to the extensive work on molecular manipulation of lignification, similar research with regard to cellulose synthesis is just beginning. Delmer (1999) has recently reviewed both the history and current status of research on cellulose synthesis. Acetobacter xylinium has long served as the model organism for research on cellulose synthesis because researchers have failed in their attempts to induce plant tissues cultures to produce cellulose. In 1990, a cellulose synthase gene 
was cloned from this bacterium (Saxena et al. 1990). In 1996, Delmer's group finally cloned two cDNAs for cellulose synthase from a cotton fiber library that showed only limited homology to the bacterial cellulose synthase gene (Pear et al. 1996). Identification of the four domains required for UDP-glucose binding allowed identification of the plant homologs to the bacterial gene. A recent search of GenBank indicated that additional cellulase synthase genes have been isolated from Arabidopsis, rice, and poplar. Unpublished work, cited by Delmer (1999), indicated that ESTs for cellulase synthase have been identified in maize. As observed for most genes in the lignin pathway, numerous copies of cellulase synthase have been found in individual plant species (Delmer 1999).

Many transgenic plants have been created with several different lignin genes, but there have been few reports of similar transgenic experiments with regard to cellulose synthesis. Arioli et al. (1998) showed that the rsw-1 Arabidopsis mutant was due to a defect in a cellulose synthase gene and complementation with the normal gene restored the wild-type phenotype to transgenics created from the $r s w-1$ mutant. Insertion of an antisense wild type $R S W-1$ cellulose synthase gene construct into Arabidopsis resulted in most of the same growth abnormalities as observed in the original mutant, although the phenotypes were unstable and tended to revert to wild type (Burn et al. 1998). The only other reported transgenic experiment dealing with cellulose synthesis examined the addition of the cellulose binding domain gene from the endo-1,4-\$-glucanase of Clostridium cellulovorans on plant growth (Shani and Shoseyov 1999). Young transgenic poplar trees grew more rapidly with insertion of the cellulose binding domain transgene. When the cellulose binding domain protein was

added to cultures of Acetobacter xylinum, cellulose synthesis increased in a dose-responsive manner (Shpigel et al. 1998). Addition of the cellulose binding domain protein to culture media also enhanced peach (Prunus persica Batsch.) pollen tube elongation and Arabidopsis root elongation. The mode of action hypothesized for this increased plant elongation is that the cellulose binding domain protein competes with xyloglucans for binding to individual \$-1,4 glucan chains, thereby temporarily preventing hydrogen bonding in cellulose microfibrils (Shani and Shoseyov 1999; Shpigel et al. 1998).

\section{Other Cell-Wall Polysaccharides}

Synthesis of hemicelluloses and pectins requires the transformation of UDP-glucose to other sugar residues (xylose, arabinose, galactose, rhamnose, mannose, galacturonic acid, and glucuronic acid) (Reiter 1994). GDP-mannose is converted to GDP-fucose by a separate pathway (Fig. 6). These sugars are then assembled into complex, branched polysaccharides by as yet unidentified enzymes. Unlike lignin synthesis which occurs in the cell wall itself and cellulose which is synthesized at the plasma membrane, hemicelluloses and pectins are assembled intracellularly in the Golgi (Delmer and Stone 1988). Feruloylation of arabinoxylans in grasses also occurs during this intra-cellular assembly process (Myton and Fry 1994). While extensive literature exists on hemicellulose and pectin structures, lack of knowledge concerning the synthesis of polysaccharides has severely limited progress toward manipulation of the pathways. 


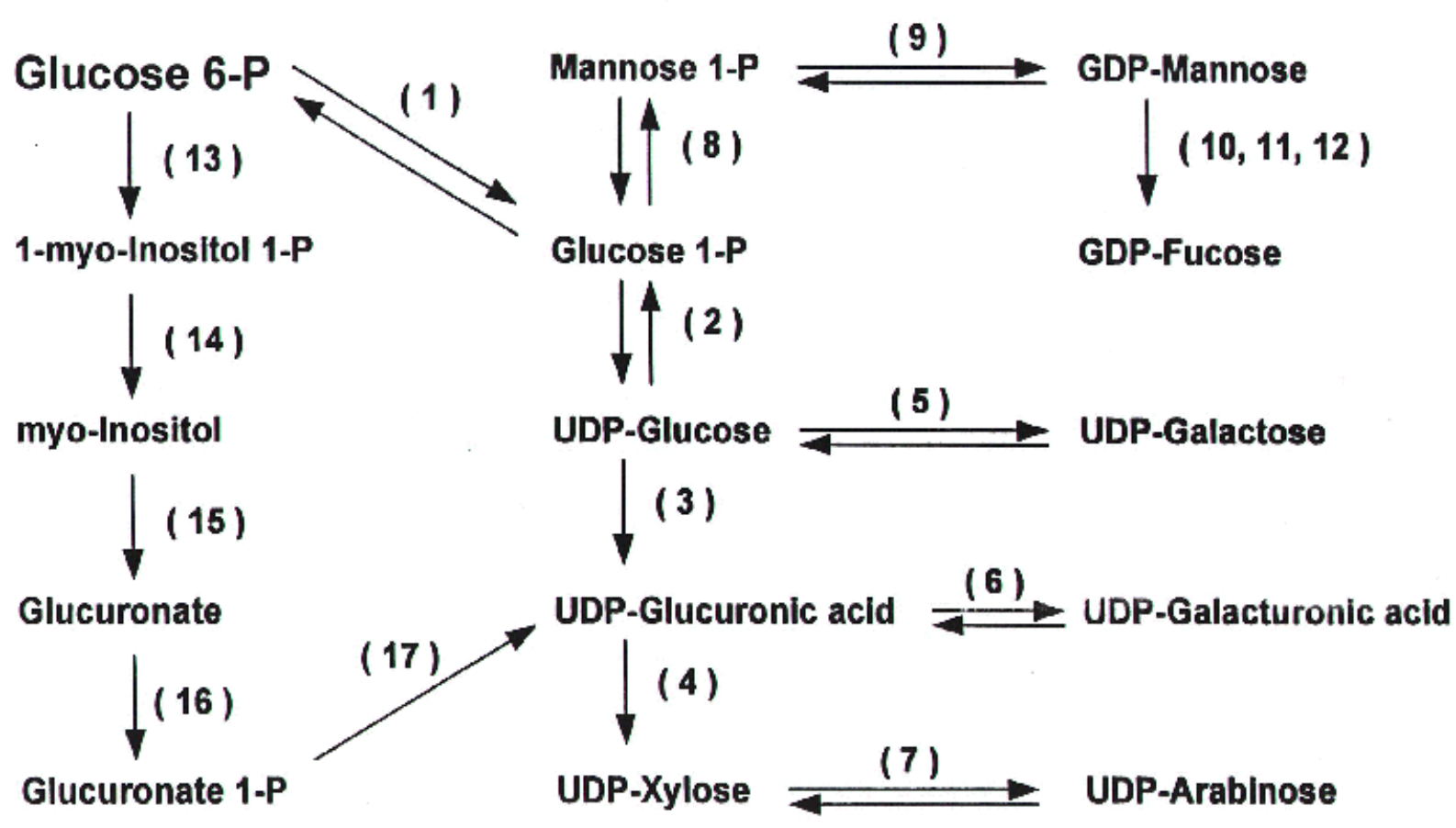

Fig. 6. The biosynthetic pathway for the major sugars that serve as cell-wall polysaccharide precursors. The enzymes involved in these sugar interconversions include: phosphoglucomutase (1); UDP-glucose pyrophosphorylase (2); UDP-glucose dehydrogenase (3); UDP-glucuronic acid decarboxylase (4); UDP-glucose epimerase (5); UDPglucuronic acid epimerase (6); UDP-xylose epimerase (7); mutase (8); GDP-mannose pyrophosphorolase (9); GDPmannose-4,6-dehydratase (10); 3,5 epimerase (11); 4-reductase (12); 1-myo-inositol 1-P synthase (13); myo-inositol 1-phosphatase (14); myo-inositol oxygenase (15); glucuronokinase (16); and UDP-glucuronic acid pyrophosphorylase (17). 
The only characterized mutations for hemicellulose and/or pectin deposition in the cell walls of plants were derived from a screening project involving 5000 chemically mutagenized Arabidopsis plants (Reiter et al. 1993). Leaf cell walls were analyzed for major shifts in sugar composition in this study. Mutants were categorized into those lines that (1) had complex changes in relative amounts of several sugars, (2) a substantial reduction in a single sugar constituent of the cell wall, or (3) lines that were completely deficient in a specific cell wall sugar (Reiter 1994). Category 1 mutants had altered growth characteristics and category 2 lines had substantial reductions in arabinose or fucose without any change in growth habit from the wild-type plants. The murl mutant of Arabidopsis was severely deficient in fucose content ( $<2 \%$ of normal) and the only line falling in category 3 (Reiter et al. 1993). This mutation caused a slight dwarfing and decreased apical dominance. Cell-wall fucose in the roots was only reduced by $40 \%$ in the murl plants compared to the almost complete absence of fucose in leaf cell walls. Recently, the murl mutation was shown to be due to a defect in the GDP-mannose-4,6-dehydratase gene that catalyzes the first step in the conversion of GDP-mannose to GDP-fucose (Bonin et al. 1997).

Only five other genes for cell-wall sugar synthesis have been cloned to date. The UDP-glucose pyrophosphorylase gene has been cloned from potato and barley (Katsube et al. 1990; Eimert et al. 1996). This gene encodes the enzyme for conversion of glucose 1-phosphate to UDP-glucose. The gene for UDP-glucose epimerase has been isolated from Arabidopsis (Dormann and Benning 1996) and the UDP-glucose dehydrogenase gene has been isolated from soybean (Glycine max (L.) Merr.) (Tenhaken and Thulke 1996). These enzymes convert UDP-glucose to UDP-galactose and UDP-glucuronic acid, respectively. These reactions are involved in synthesis of the precursors to both hemicellulose and pectin. The UDP-glucose dehydrogenase enzyme has been hypothesized to be a key regulatory step for hemicellulose synthesis because it transfers carbon from glucose to the pentose sugars (xylose and arabinose) (Amino et al. 1985). The GDP-mannose pyrophosphorylase gene, which converts mannose to fucose, has been cloned from potato (Solanum tuberosum L.) (Keller and Kossmann 1998). Most recently, Perrin et al. (1999) reported the isolation of a xyloglucan fucosyltransferase from Arabidopsis. This is the first gene that has been cloned for a step in hemicellulose assembly.

There has been only one published report with transgenic plants concerning the synthesis of hemicellulose or pectin. Reduction of GDP-mannose pyrophosphorylase activity by a transgene from potato resulted in reduced mannose concentration in the leaves, but did not reduce fucose content as expected, and resulted in premature senescence as the plants matured (Keller and Kossmann 1998). One of the authors of this review (HGJ) is involved in an attempt to increase pectin deposition in alfalfa by addition of a sense construct of the soybean UDP-glucose dehydrogenase gene because of this enzyme's presumed regulatory role in sugar interconversions for cell-wall polysaccharide synthesis (Amino et al. 1985). While presence of the transgene has increased UDP-glucose dehydrogenase activity in transgenic alfalfa plants, its impact on pectin concentration in the cell wall has not yet been determined (Jung, Samac, and Somers, unpublished). The extreme paucity of information on polymer synthesis of the non-cellulosic polysaccharides and very limited number of genes cloned for sugar precursor synthesis undoubtedly accounts for the lack of transgenic attempts to manipulate hemicellulose and pectin synthesis.

As indicated above, there are an array of synthesis pathways in herbaceous plants such as switchgrass that could be genetically manipulated via plant transformation. Creation and characterization of an expanded array of cell wall mutants in grasses would tremendously aid our study of polysaccharide biosynthesis and subsequent cloning of the genes involved in cell wall composition and assembly. However, until the conversion technology is known and desirable feedstock parameters are delineated, it will be difficult for geneticists to know what genes to use in plant transformation research to improve the feedstock qualities of switchgrass. Transformation technology may be needed to develop switchgrass plants for biomass that produce only sterile pollen (see section on environment and ecosystem constraints on the use of genetically modified organisms). 


\section{ENVIRONMENT AND ECOSYSTEM CONSTRAINTS ON THE USE OF GENETICALLY MODIFIED ORGANISMS}

There is currently considerable debate over the desirability and safety of transgenic plants and

the issue is complicated because the arguments against the use of genetically modified organisms are based on scientific, economic, political, and religious grounds (Duvick 1999). As pointed out by Duvick (1999), the primary scientific issue is safety. Transformed biomass plants must be safe for use by animals (domestic or wild) and also be ecologically safe to be utilized in production systems. They must not have the capacity to develop into super weeds. Their potential for affecting germ plasm resources also needs to be considered and this is the main issue that could limit the use of transformed plants in biomass production systems.

Switchgrass was one of the dominant grasses of the North American Tallgrass Prairie and it is generally associated with the natural vegetation of the Great Plains and the western Corn Belt (Moser and Vogel 1995). It was also found in grasslands and non-forested area throughout North America east of the Rocky Mountains and south of $55^{\circ} \mathrm{N}$ latitude. Tallgrass Prairie is a recently derived vegetation type (Steinauer and Collins 1996). There was probably a woodland-grassland mosaic on the plains and prairies of North America before the Pleistocene. During the Pleistocene, the eastern Great Plains was covered by ice in the North and forest in the South. It was not until the Holocene that conditions conductive to continuous grasslands existed on the plains and prairies (Steinaurer and Collins 1996). The Tallgrass Prairie existed as an ecosystem for over 12,000 years. In less than a 100 years, it has been largely converted to cultivated cropland. Except in the Great Plains states where extensive natural grasslands still exist in some regions, the native prairie and grassland sites where switchgrass occurs are scattered remnants. Since 1930, the decline (estimated to be 82-99\%) in area of the Tallgrass Prairie exceed those reported for any other major ecosystem (Sampson and Knopf 1994). Only about 4\% of the pre-settlement Tallgrass Prairie remains. Throughout its former range, only small scattered fragments remain embedded in the non-grassland landscape (Steinaurer and Collins 1996, Risser 1996). Of The Nature Conservancy's 101 tall grass prairie preserves, 71 are less than 100 ha and only 4 are greater that 1000 ha (Steinaurer and Collins 1996). These small remnant prairies and grasslands constitute the in situ germ plasm preservation reserve of switchgrass. The situation is similar in the eastern regions of the range of switchgrass in the North America.

Since the germ plasm base for switchgrass consists of scattered small remnant populations there is concern among conservation biologists, including The Nature Conservancy staff that species in these remnant populations could be genetically contaminated by native grass, legume, and forb cultivars developed using conventional breeding methods. Frye (1999) recently discussed the potential problems that could occur due to gene transfer via seed or pollen and they include: loss of genetic diversity by swamping of native genotypes or by the introduction of aggressive strains; loss of populations sizes and structure through the introduction of deleterious or lethal alleles; loss of evolutionary potential through genetic homogenization; unforeseen changes in plant-animal interactions; and loss of research potential utilizing native populations. Frye (1999) concluded that outbreeding contamination may not be a problem with long-lived perennials (such as switchgrass) but could likely be a problem with outcrossing annual species. This is an area of concern with The Nature Conservancy, which is one of the largest holders of remnant prairie and other grassland sites (Grove 1988). The USDA-ARS Grassland Research Project at the University of Nebraska-Lincoln (co-author Vogel and others) initiated a project in 1999 to collect native legume germ plasm from remnant central Great Plains and adjacent midwest states. One of the reasons for collecting the native legumes was to use them in research to identify species that could be grown with switchgrass in biomass production fields to reduce the requirement for $\mathrm{N}$ fertilizer. Permission to collect from Nature Conservancy sites required extensive plans and documentation on the intended use of the 
germ plasm because of the concern that this material would be used to develop cultivars that when deployed in grassland agriculture could contaminate remnant populations.

The deployment of transgenic switchgrass plants, particularly if they were altered with genes that could potentially affect fitness, would most likely be of major concern to many environmental groups in North America. Many of the groups that would likely be strongly politically opposed to the deployment of transgenic switchgrass plants are also those who currently are some of most the significant supporters of renewable biomass energy programs.

Transgenic switchgrass plants will be able to be released for use in biomass production systems only if their potential for genetic contamination of remnant switchgrass populations is virtually zero. Because genetic contamination can occur via seed or pollen, transgenic switchgrass plants must not be capable of producing either viable seed or pollen when grown in biomass production fields.

Technology has recently been developed that could be used in switchgrass to eliminate the feasibility of viable seeds being produced. This is the Technology Protection System or 'Terminator' technology that was jointly developed by the Agricultural Research Service, U.S. Department of Agriculture and the Delta and Pine Land Company, which is a major breeder of cotton (Gossypium hirsutum L.) and soybeans, and they have received U.S. Patent 5,723,765 on the technology (Service 1998; United States Patent Office 1999; USDA-ARS 1999). The patent is jointly owned by USDA-ARS and Delta and Pine Land Co. and under the terms of the development agreement, Delta and Pine Land Co. have licensing rights. In a recent USDA-ARS Fact Sheet (USDA-ARS 1999), ARS indicated that the technology would be made widely available for research in the public and private sectors and that Delta and Pine Land Co. has agreed to make the technology widely available for sublicensing to other seed companies.

Similar technology to produce plants that do not produce viable pollen has not been developed to date. Male sterile genes exist in most plants species and it is likely that some mechanism involving manipulation of male sterility could be developed. In contrast to crops in which seed is the primary product and for which viable pollen is needed to produce a crop, a biomass crop does not have to produce seed. Seed is needed only to establish production fields. Technology to eliminate the production of viable pollen in switchgrass or other herbaceous biomass crops but still enable seed to be produced in seed production fields will probably be needed before genetically transformed switchgrass plants will be able to be released for use in agricultural production.

\section{DEVELOPMENT OF A BIOMASS FEEDSTOCK QUALITY ASSESSMENT PROGRAM FOR DETERMINING AND MONITORING FEEDSTOCK QUALITY}

Information in the previous sections have clearly demonstrated that switchgrass and other herbaceous biomass feedstocks can vary in desirable quality traits due to differences in date of harvest, environment during the growing season, harvesting and storage practices, and because of inherent genetic differences among the strains. Variation in biomass quality due to a combination of all the nongenetic factors can likely exceed any genetic differences among strains. Even if producers follow rigid guidelines in producing and storing biomass feedstocks, there still will be significant differences in biomass quality due to uncontrollable environmental effects. Feedstocks stored under very undesirable conditions may even be totally unusable in a conversion plant and methods of detecting bad lots of biomass feedstocks will be needed. If feedstock quality is a determining factor in the efficiency of the conversion process, and it likely will be, then a mechanism must be in place to determine and measure feedstock quality at the factory gate. If switchgrass cultivars are developed with improved processing characteristics via genetic manipulation, there needs to be an economic incentive for producers to grow the strains with improved conversion qualities. Feedstock quality must be one of the factors determining feedstock price. 
Biomass conversion plants will need the capability to measure feedstock quality rapidly, reliably, and accurately. Fortunately, a technology has been developed that can be used to meet these criteria. It is near infrared reflectance spectroscopy or NIRS (Shenk and Westerhouse 1994, 1995). This technology was developed to determine quality of agricultural products including protein and oil content of grains and oilseeds, and was adapted to measure forage quality parameters. With this technology, ground samples are scanned with near-infrared radiation in monochromatic 2 to $10 \mathrm{~nm}$ increments in the 700 to $2500 \mathrm{~nm}$ near-infrared region and the reflected radiation is measured. The spectrum of the sample can then be statistically compared to the spectra from a set of calibration samples and its chemical composition can be determined. The calibration samples must be representative of the range of plant materials expected to be analyzed and the composition of the calibration samples must be determined using standard procedures. With current technology, it is feasible to probe and collect switchgrass biomass feedstock samples from a truckload of feedstock at the factory gate, dry the samples in a microwave oven, grind the samples in a highspeed bench top grinder to a 1 or $2 \mathrm{~mm}$ standardized grind particle size, subsample the ground material, scan the subsample, and have feedstock quality values in less than 30 minutes. NIRS has been demonstrated to be an effective technology that can be used to determine IVDMD, NDF, ADF, cell wall total monosaccharides, arabinose, xyulose, galactose, glucose, hexose, and pentose sugars of switchgrass and other grasses (de Ruiter and Burns 1987; de Ruiter et al. 1988; and Godshalk et al. 1988b).

Much of the high quality hay sold in interstate commerce in the United States is sold on a quality basis as determined by NIRS. The protocols that have been developed to sample and analyze truckloads of hay can be utilized to develop similar systems for biomass feedstocks. It will be necessary to collect representative calibration samples, analyze them and develop robust and accurate calibration samples. Procedures for implementing an NIRS Biomass Feedstock Quality Assessment Program are available (Shenk and Westerhaus 1994 1995; Marten et al. (1989). It is feasible to develop robust calibration equations for large geographical regions. A system of this type has been developed for use by the Minnesota Valley Alfalfa Producers as part of the Minnesota AgriPower Project (co-author H.G. Jung has participated in research for this project). NIRS has been used by the NE-ARS switchgrass breeding program for over 10 years to analyze switchgrass forage for IVDMD, NDF, ADF, and ADL in both breeding and genetics studies and a library of scans and associated laboratory data has been accumulated for switchgrass grown in the Midwest and harvested at varying stages of maturity. This library of scans and associated laboratory data which includes IVDMD, NDF, ADF, and ADL could serve as the basis for a initial quality assessment program. Other quality parameters will require additional NIRS calibrations. 


\section{SUMMARY}

It should be highly feasible to genetically modify the feedstock quality of switchgrass and other herbaceous plants using both conventional and molecular breeding techniques. Effectiveness of breeding to modify herbages of switchgrass and other perennial and annual herbaceous species has already been demonstrated. The use of molecular markers and transformation technology will greatly enhance the capability of breeders to modify the plant structure and cell walls of herbaceous plants. It will be necessary to monitor gene flow to remnant wild populations of plants and have strategies available to curtail gene flow if it becomes a potential problem. It also will be necessary to monitor plant survival and long-term productivity as affected by genetic changes that improve forage quality.

Information on the conversion processes that will be used and the biomass characteristics that affect conversion efficiency and rate is absolutely essential as well as information on the relative economic value of specific traits. Because most forage or biomass quality characteristics are highly affected by plant maturity, it is suggested that plant material of specific maturity stages be used in research to determining desirable feedstock quality characteristics. Plant material could be collected at various stages of development from an array of environments and storage conditions that could be used in conversion research. The same plant material could be used to develop NIRS calibrations that could be used by breeders in their selection programs and also to develop criteria for a feedstock quality assessment program.

Breeding for improved feedstock quality will likely affect the rate of improvement of biomass production per acre. If the same level of resources are used, multi-trait breeding simply reduces the selection pressure and hence the breeding progress that can be made for a single trait unless all the traits are highly correlated. Since desirable feedstock traits are likely to be similar to IVDMD, it is likely that they will not be highly positively correlated with yield. Hence to achieve target yields and improve specific quality traits, it will likely be necessary to increase the resources available to plant breeders. Marker assisted selection will be extremely useful in breeding for quality traits, particularly for traits that can be affected by modifying a few genes. Genetic markers are going to be needed for monitoring gene flow to wild populations. Transformation will be a very useful tool for determining the affects of specific genes on biomass feedstock quality. 


\section{LITERATURE CITED}

Alexandrova, K. S., P.D. Denchev and B.V. Conger. 1996a. In vitro development of inflorescences from switchgrass nodal segments. Crop Sci. 36:175-178.

Alexandrova, K. S., P.D. Denchev and B.V. Conger. 1996b. Micropropagation of switchgrass by node culture. Crop Sci. 36:1709-1711.

Allard, R. W. 1964. Principles of plant breeding. John Wiley \& Sons, New York.

Amino, S., Y. Takeuchi, and A. Komamine. 1985. Changes in enzyme activities involved in formation and interconversion of UDP-sugars during the cell cycle in a synchronous culture of Catharanthus roseus. Physiol. Plant. 60: 111-117.

Anderson, Bruce, J. K. Ward, K. P. Vogel, M. G. Ward, H.J.Gorz, and F. A. Haskins. 1988. Forage quality and performance of yearlings grazing switchgrass strains selected for differing digestibility. J. Anim. Sci. 66:2239- 2244.

Arioli, T., L. Peng, A. S. Betzner, J. Burn, W. Wittke, W. Herth, C. Camilleri, H. Hofte, J. Plazinski, R. Birch, A. Cork, J. Glover, J. Redmond, and R. E. Williamson. 1998. Molecular analysis of cellulose biosynthesis in Arabidopsis. Science 279: 717-720.

Atanassova, R., N. Favet, F. Martz, B. Chabbert, M.-T. Tollier, B. Monties, B. Fritig, and M. Legrand. 1995. Altered lignin composition in transgenic tobacco expressing $O$-methyltransferase sequences in sense and antisense orientation. Plant J. 8: 465-477.

Baker, R. J. 1986. Selection Indices in Plant Breeding. Boca Raton, FL: CRC Press

Baucher, M., B. Monties, M. Van Montagu, and W. Boerjan. 1998. Biosynthesis and genetic engineering of lignin. Crit. Rev. Plant Sci. 17: 125-197.

Bonin, C. P., I. Potter, G. F. Vanzin, and W.-D. Reiter. 1997. The MURI gene of Arabidopsis thaliana encodes an isoform of GDP-D-mannose-4,6-dehydratase, catalyzing the first step in the de novo synthesis of GDP-L-fucose. Proc. Natl. Acad. Sci. USA 94: 2085-2090.

Brummer, E.C. 1998. Molecular and cellular technologies in forag improvement: an overview. p. 1-10. In E.C. Brummer, N.S. Hill, C.A. Roberts (eds). Molecular and Cellular Technologies for forage improvement. p.11-24. CSSA Spec. Publ. 26. CSSA, Madison, WI.

Buendgen, M. R., J. G. Coors, A. W. Grombacher and W. A. Russell. 1990. European corn borer resistance and cell wall composition of three maize populations. Crop Sci. 30: 505-510.

Burn, J. E., T. Arioli, A. Betzner, R. Birch, A. Cork, and R. E. Williamson. 1998. Cellulose biosynthesis in Arabidopsis thaliana, molecular analysis and developmental effects of reduced synthesis. 8th Int. Cell Wall Mtg., Sept. 1-5, 1998, Norwich, UK, Abstr. 1.06.

Buxton, D.R. and M.D. Casler. 1993. Environmental and genetic effects on cell wall composition and digestibility. pp. 685-714. In H.G. Jung, D.R. Buxton, R.D. Hatfield, and J. Ralph (eds.) Forage cell wall structure and digestibility. ASA. Madison, WI.

Buxton, D. R., and S. L. Fales. 1994. Plant environment and quality. p. 155-199. In G. C. Fahey, Jr., M. Collins, D. R. Mertens, and L. E. Moser (eds.). Forage Quality, Evaluation, and Utilization. ASA-CSSA-SSSA, Madison, WI.

Casler, M. D. 1999a. Phenotypic recurrent selection methodology for reducing fiber concentration of smooth bromegrass. Crop Sci. 39:381-390.

Casler, M. D. 1999b. Structural responses to selection for reduced fiber concentration in smooth bromegrass. Crop Sci. 39:1435-1438.

Casler, M. D. 1999c. Correlated Responses in forage yield and nutritional value from phenotypic recurrent selection for reduced fiber concentration in smooth bromegrass. Theo. Appl. Genet. 99:1245-1254

Casler, M. D. and H. G. Jung. 1999. Selection and evaluation of smooth bromegrass clones with divergent lignin or etherified ferulic acid concentration. Crop Sci. 39:1866-1873

Casler, M. D., and K. P. Vogel. 1999. Accomplishments and impact from breeding for increased forage nutritional value. Crop Sci. 39:12-20. 
Casler, M. D., D. R. Buxton, and K. P. Vogel (2000). Genetic correlation between nutritive value and fitness of herbaceous plants. (In internal review).

Chapple, C. C. S., T. Vogt, B. E. Ellis, and C. R. Somerville. 1992. An Arabidopsis mutant defective in the general phenylpropanoid pathway. Plant Cell 4: 1413-1424.

Collins, M., and K. J. Moore. 1995. pp.147-161. In: R. F. Barnes, D. A. Miller, and C. J. Nelson (eds). Forages II: The Science of Grassland Agriculture. Iowa State University Press, Ames, IA.

Conger, B. V. 1998. Genetic Transformation of Forage Grasses. pp. 49-58. In E.C. Brummer, N.S. Hill, C.A. Roberts (eds.). Molecular and Cellular Technologies for Forage Improvement. CSSA Special Publication Number 26.

Conger, B.V., Z. Tomaszewski, M. K. Odjakova, and H. Sun. 1999. Development of in vitro systems for switchgrass. Annual Report 1998 for Subcontract 11X-SY 161, Bioenergy Feedstock Development Program, Environmental Sciences Division, Oak Ridge National Laboratory, Oak Ridge, TN.

Deetz, D. A., H. G. Jung, and D. R. Buxton. 1994. Water-deficit effects on cell-wall composition and in vitro degradability of structural polysaccharides from alfalfa stems. Crop Sci. 36: 383-388.

Delmer, D. P. 1999. Cellulose biosynthesis: exciting times for a difficult field of study. Ann. Rev. Plant Physiol. Plant Mol. Biol. 50: 245-276.

Delmer, D. P., and B. A. Stone. 1988. Biosynthesis of plant cell walls. pp. 373-420. In: J. Preiss (ed.). The Biochemistry of Plants, Vol. 14 Carbohydrates. Academic Press, Inc., San Deigo, CA.

Denchev, P.D. and B.V. Conger 1994. Plant regeneration from callus culture of switchgrass. Crop Sci. 34:1623-1627.

de Ruiter, J. M. and Burns, J. C. 1987. Cell wall carbohydrates of flaccidgrass plant parts. III. Near infrared reflectance spectroscopy determination, rate, and extent of fermentation. Crop Sci. 27:1069-1076.

de Ruiter, J. M.; Burns, J. C.; McClure, W. F., and Timothy, D. H. 1988. Prediction of cell wall carbohydrates and quality in Panicum species by near infrared reflectance spectroscopy. Crop Sci. 28:348-353.

Dormann, P., and C. Benning. 1996. Functional expression of uridine 5'-diphospho-glucose 4epimeras (EC 5.1.3.2) from Arabidopsis thaliana in Saccharomyces cerevisiae and Escherichia coli. Arch. Biochem. Biophysics 327: 27-34.

Dutta, G.S. and B.V. Conger. 1999 Somatic embryongenesis and plant regeneration from suspension cultures of switchgrass. Crop Sci. 39:243-247.

Duvick, D. N. 1999. How much caution in the fields? Science. 286:418-419.

Dwivedi, U..N., W..H. Campbell, J. Yu, R..S..S. Datla, R..C. Bugos, V..L. Chiang, and G..K. Podila. 1994. Modification of lignin biosynthesis in transgenic Nicotiana through expression of an antisense $O$-methyltransferase gene from Populus. Plant Mol. Biol. 26: 61-71.

Eimert, K., P. Villand, A. Kilian, and L. A. Kleczkowski. 1996. Cloning and characterization of several cDNAs for UDP-glucose pyrophoshorylase from barley (Hordeum vulgare) tissues. Gene 170: 227-232.

Engels, F..M., and H..G. Jung. 1998. Alfalfa stem tissues: cell-wall development and lignification. Ann. Bot. 82: 561-568.

Falconer, D. S. 1981. Introduction to quantitative genetics 2nd ed. Longman Inc., New York.

Fehr, W. R. and H. H. Hadley (eds.) 1980. Hybridization of crop plants. Am. Soc. of Agron. Crop Sci. Soc. of Am., Madison, WI.

Frye, C. T. 1999. Non-native genotypes \& outbreeding depresssion in plants: theoretical \& impirical issues. p. 16. The Second Eastern Native Grass Symposium. November 17th to 19th, Baltimore, MD, Natural Resources Conservation Service, USDA. 
Fritz, J. O., K. J. Moore, and K. P. Vogel. 1991. Ammonia-labile bonds in high and low digestibility strains of switchgrass. Crop Sci. 31:1566-1570.

Gabrielsen, B. C., K. P. Vogel, B. E. Anderson, and J. K. Ward. 1990. Alkali-labile lignin phenolics and forage quality in three switchgrass strains selected for differing digestibility. Crop Sci. 30:1313-1320.

Godshalk, E. B, J. C. Burns, and D. H. Timothy. 1988a. Effectiveness of index selection for switchgrass forage yield and quality. Crop Sci. 28:825-830.

Godshalk, E. B., W. F. McClure, J. C. Burns, D. H. Timothy, and D. S. Fisher. 1988b. Heritability of cell wall carbohydrates in switchgrass. Crop Sci. 28:736-742.

Grove, N. 1998. Quietly conserving nature. National Geographic. Dec. 818-844.

Griffin, J. L., and G. A. Jung. 1983. Leaf and stem forage quality of big bluestem and switchgrass. Agron. J. 75: 723-726.

Gunter, L. E., G.A. Tuskan and S.D. Wullschleger. 1996. Diversity among populations of switchgrass based on RAPD markers. Crop Sci. 36: 1017-1022.

Halim, R. A., D. R. Buxton, M..J. Hattendorf, and R. E. Carlson. 1989. Water-stress effects on alfalfa forage quality after adjustment for maturity differences. Agron. J. 81: 189-194.

Hallauer, A. R. and J. B. Miranda. 1981. Quantitative genetics in maize breeding. Iowa State University Press. Ames, IA.

Halpin, C., K. Holt, J. Chojecki, D. Oliver, B. Chabbert, B. Monties, K. Edwards, and G..A. Foxon. 1998. Maize brown-midrib (bm1) - a mutation affecting the cinnamyl alcohol dehydrogenase gene. Plant J. 14: 545-553.

Hatfield, R..D. 1993. Cell wall polysaccharide interactions and degradability. pp. 286-313. In: H. G. Jung, D. R. Buxton, R. D. Hatfield, and J. Ralph (eds.). Cell Wall Structure and Digestibility. ASA-CSSA-SSSA, Madison, WI..

Hatfield, R. D., H. G. Jung, J. Ralph, D. R. Buxton, and P. J. Weimer. 1994. A comparison of the insoluble residues produced by the Klason lignin and acid detergent lignin procedures. J. Sci. Food Agric. 65: 51-58.

Hatfield, R. D., J. R. Wilson, and D. R. Mertens. 1999. Composition of cell walls isolated from cell types of grain sorghum stems. J. Sci. Food Agric. 79: 891-899.

Hibino, T., K. Takabe, T. Kawazu, D. Shibata, and T. Higuchi. 1995. Increase of cinnamaldehye groups in lignin of transgenic tobacco plants carrying an antisense gene for cinnamyl alcohol dehydrogenase. Biosci. Biotech. Biochem. 59: 929-931.

Hill, R. R., Jr. 1981. Selection for phosphorus and lignin content in alfalfa. $27^{\text {th }}$ Alfalfa Improvement Conference, Madison, WI. July 8-10, 1980. Peoria, IL: USDA-ARS North Central Region.

Hopkins, A. A. 1993. Genetic variation among switchgrasses for agronomic, forage quality, and biofuel traits. Ph.D. Dissertation. University of Nebraska-Lincoln, Lincoln, NE. (Diss. Abstr. 1307730)

Hopkins, A. A., K. P. Vogel, and K. J. Moore. 1993. Predicted and realized gains from selection for in vitro dry matter digestibility and forage yield in switchgrass. Crop Sci. 253-258.

Hopkins, A. A., K. P. Vogel, K. J. Moore, K. D. Johnson, and I. T. Carlson. 1995a. Genotype effects and genotype by environment interactions for traits of elite switchgrass populations. Crop Sci. 35:125-132.

Hopkins, A. A., K. P. Vogel, K. J. Moore, K. D. Johnson, and I. T. Carlson. 1995b. Genetic variability and genotype $\mathrm{x}$ environment interactions among switchgrass accessions from the Midwestern USA. Crop Sci. 35: 565-571.

Hu, W-J., S. A. Harding, J. Lung, J. L. Popko, J. Ralph, D. D. Stokke, C-J. Tsai, and V. L. Chiang. 1999. Repression of lignin biosynthesis promotes cellulose accumulation and growth in transgenic trees. Nature Biotechnol. 17: 808-812.

Hultquist, S. J., K. P. Vogel, D. J. Lee, K. Arumuganathan, and S. Kaeppler. 1996. Chloroplast DNA and nuclear DNA content variations among cultivars of switchgrass, Panicum virgatum L. Crop Sci.36:1049-1052. 
Jung, H. G., M. D. Casler, W. Ni, and R. L. Phiilips. 1999a. Reduction of ferulate ester deposition and cross-linking improves cell-wall digestibility of grasses. J. Dairy Sci. 82 (Suppl. 1): 39-40.

Jung, H. G., and D. A. Deetz. 1993. Cell wall lignification and degradability. pp. 315-346. In H. G. Jung, D. R. Buxton, R. D. Hatfield, and J. Ralph (eds.). Forage Cell Wall Structure and Digestibility. ASA-CSSA-SSSA, Madison, WI.

Jung, H. G., D. R. Mertens, and A. J. Payne. 1997a. Correlation of acid detergent lignin and Klason lignin with digestibility of forage dry matter and neutral detergent fiber. J. Dairy Sci. 80: $1622-1628$.

Jung, H. G., and W. Ni. 1998. Lignification of plant cell walls: impact of genetic manipulation. Proc. Natl. Acad. Sci. USA 95: 12742-12743.

Jung, H. G., C. C. Sheaffer, D. K. Barnes, and J. L. Halgerson. 1997b. Forage quality variation in the U.S. alfalfa core collection. Crop Sci. 37: 1361-1366.

Jung, H. G., V. H. Varel, P. J. Weimer, and J. Ralph. 1999b. Accuracy of Klason lignin and acid detergent lignin methods as assessed by bomb calorimetry. J. Agric. Food Chem. 47: 2005-2008.

Jung, H. G., and K. P. Vogel. 1992. Lignification of switchgrass (Panicum virgatum L.) and big bluestem (Andropogon gerardii Vitman) plant parts during maturation and its effect on fibre degradability. J. Sci. Food Agric. 59: 169-176.

Kalu, B. A., and G. W. Fick. 1983. Morphological stage of development as a predictor of alfalfa herbage quality. Crop Sci. 23: 1167-1172.

Katsube, T., Y. Kazuta, H. Mori, K. Nakano, K. Tanizawa, and T. Fukui. 1990. UDP-glucose pyrophosphorylase from potato tuber: cDNA cloning and sequencing. J. Biochem. 108: 321-326.

Keller, R., and J. Kossmann. 1998. Genetic modification of matrix polysaccharides. 8th Int. Cell Wall Mtg., Sept. 1-5, 1998, Norwich, UK, Abstr. 1.04.

Kephart, K. D., D. R. Buxton, and R. R. Hill, Jr. 1989. Morphology of alfalfa divergently selected for herbage lignin concentration. Crop Sci. 29: 778-782.

Kephart, K. D., D. R. Buxton, and R. R. Hill, Jr. 1990. Digestibility and cell-wall components of alfalfa following selection for divergent herbage lignin concentration. Crop Sci. 30: 207-212.

Kokubo, A., S. Kuraishi, and N. Sakurai. 1989. Culm strength of barley. Correlation among maximum bending stress, cell wall dimensions, and cellulose content. Plant Physiol. 91: 876-882.

Kokubo, A., N. Sakurai, S. Kuraishi, and K. Takeda. 1991. Culm brittleness of barley (Hordeum vulgare L.) mutants is caused by smaller number of cellulose molecules in cell wall. Plant Physiol. 97: 509-514.

Kondo, T., K. Mizuno, and T. Kato. 1987. Variation in solubilities of lignin in acid detergent and in alkali. J. Japan. Grassl. Sci. 33: 296-299.

Knapp, S.J. 1998. Marker-assisted selection as a strategy for increasing the probability of selection using superior genotypes. Crop Sci. 38:1164-1174.

Lee, D., K. Meyer, C. Chapple, and C. J. Douglas. 1997. Antisense suppression of 4coumarate:coenzyme A ligase activity in Arabidopsis leads to altered lignin subunit composition. Plant Cell 9: 1985-1998.

Li, L. G., Y. Osakabe, C. P. Joshi, and V. L. Chiang. 1999. Secondary xylem-specific expression of caffeoyl-coenzyme A 3-O-methyltransferase plays an important role in the methylation pathway associated with lignin biosynthesis in loblolly pine. Plant Mol. Biol. 40: 555-565.

Li, L., J. L. Popko, T. Umezawa, and V. L. Chiang. 2000. 5-Hydroxyconiferyl aldehyde modulates enzymatic methylation for syringyl monolignol formation, a new view of monolignol biosynthesis in angiosperms. J. Biol. Chem. (in press).

Liu, B. H. 1998. Statistical genomics: linkage, mapping, and QTL analysis. CRC Press LLC, Boca Raton, Fla. 
Lowry, J. B., L. L. Conlan, A. C. Schlink, and C. S. McSweeney. 1994. Acid detergent dispersible lignin in tropical grasses. J. Sci. Food Agric. 65: 41-49.

Lubberstedt, T., A. E. Melchinger, D. Klein, H. Degenhardt, and C. Paul. 1997. QTL mapping in testcrosses of European flint lines of maize: II. Comparison of different testers for forage quality traits. Crop Sci. 37: 1913-1922.

MacKay, J. J., D. M. O'Malley, T. Presnell, F. L. Booker, M. M. Campbell, R. W. Whetten, and R. R. Sederoff. 1997. Inheritance, gene expression, and lignin characterization in a mutant pine deficient in cinnamoyl alcohol dehydrogenase. Proc. Natl. Acad. Sci. 94: 8255-8260.

Mandebvu, P., J. W. West, G. M. Hill, R. N. Gates, R. D. Hatfield, B. G. Mullinix, A. H. Parks, and A. B. Caudle. 1999. Comparison of Tifton 85 and Coastal bermudagrass for yield, nutrient traits, intake, and digestion by growing beef steers. J. Anim. Sci. 77: 1572-1586.

Marten, G. C., J. S. Shenk, and F. E. Barton, (eds). 1989. Near Infrared Reflectance Spectroscopy (NIRS): Analysis of Forage Quality. USDA-ARS Agric Handbook. 643 (revised with supplements), 110 p. U.S. Gov. Print. Off., Washington, D.C.

Martinez-Reyna, J. M. and K.P. Vogel. 1998 Controlled hybridization technique for switchgrass. Crop Sci. 38: 876-878.

Mitchell, R. B., K. J.Moore, L. E. Moser, J. O. Fritz, and D. D. Redfern. 1997. Predicting developmental morphology in switchgrass and big bluestem. Agron. J. 89:827-832.

Mitchell, R. B., J. O. Fritz, K. J. Moore, L. E. Moser, K. P. Vogel, and D. D. Redfern, 2000. Predicting forage quality in switchgrass and big bluestem. Agron. J. (In review).

Moore, K. J., L. E. Moser, K. P. Vogel, S. S. Waller, B. E. Johnson, and J. F. Pedersen. 1991. Describing and quantifying growth stages of perennial forage grasses. Agron. J. 83:1073-1077.

Moore, K. J., K. P. Vogel, A. A. Hopkins, J. F. Pedersen, and L. E. Moser. 1993. Improving the digestibility of warm-season perennial grasses. pp. 447-448. Proc. XVII Int. Grassland Congress. New Zealand Grassland Society, NZ.

Morrison, I. M. 1980. Hemicellulosic contamination of acid detergent residues and their replacement by cellulosic residues in cell wall analysis. J. Sci. Food Agric. 31: 639-645.

Moser, L. E., and K. P. Vogel. 1995. Switchgrass, big bluestem, and indiangrass. Chapter 32. pp. 409-420. In R .F. Barnes, D. A. Miller, and C. J. Nelson (eds.). Forages, 5th ed. Vol.I: An introduction to grassland agriculture. Iowa State Univ. Press, Ames, IA.

Myton, K., and S. C. Fry. 1994. Intraprotoplasmic feruloylation of arabinoxylans in Festuca arundinacea cell cultures. Planta 193: 326-330.

Nelson, C. J. and J. J. Volenec. 1995. Environmental and physiological aspects of forage management. pp. 55-69. In Robert F. Barnes, Darrell A. Miller, and C. Jerry Nelson (eds.). Forages, 5th ed. Vol.I: An introduction to grassland agriculture. Iowa State Univ. Press., Ames, IA.

Neuffer, M. G., L. Jones, and M. S. Zuber. 1968. The mutants of maize. CSSA, Madison, WI. p. 74.

Ni, W., N. L. Paiva, and R. A. Dixon. 1994. Reduced lignin in trangenic plants containing a caffeic acid O-methytransferase antisense gene. Transgenic Res. 3: 120-126.

Ni, W., R. L. Phillips, and H. G. Jung. 1997. Search for the gene(s) controlling ferulic acid crosslinking of lignin and polysaccharides in maize cell walls. Keystone Symp., Copper Mountain, CO. p. 24.

Ni, W., R. L. Phillips, and H. G. Jung. 1998. Quantitative trait loci for cell-wall traits in maize. 8th Int. Cell Wall Mtg., November 1-5, 1998, Norwich, UK, Abstr. 1.38.

Osakabe, K., C. C. Tsao, L. G. Li, J. L. Popko, T. Umezawa, D. T. Carraway, R. H. Smeltzer, C. P. Joshi, and V. L. Chiang. 1999. Coniferyl aldehyde 5-hydroxylation and methylation direct syringyl lignin biosynthesis in angiosperms. Proc. Natl. Acad. Sci. USA 96: 8955-8960.

Ostrander, B. M. and J. G Coors. 1997. Relationship between plant composition and European corn borer resistance in three maize populations. Crop Sci. 37:1741-1745. 
Pear, J., Y. Kawagoe, W. Schreckengost, D. P. Delmer, and D. Stalker. 1996. Higher plants contain homologs of the bacterial CelA genes encoding the catalytic subunit of the cellulose synthase. Proc. Natl. Acad. Sci. 93: 12637-12642.

Perrin, R. M., A. E. DeRocher, M. Bar-Peled, W. Zeng, L. Norambuena, A. Orellana, N. V. Raikhel, and K. Keegstra. 1999. Xyloglucan fucosyltransferase, an enzyme involved in plant cell wall biosynthesis. Science 284: 1976-1979.

Piquemal, J., C. Lapierre, K. Myton, A. O'Connell, W. Schuch, J. Grima-Pettenati, and A.-M. Boudet. 1998. Down-regulation of cinnamyl-CoA reductase induces significant changes of lignin profiles in transgenic tobacco plants. Plant J. 13: 71-83.

Potikha, T., and D. P. Delmer. 1995. A mutant of Arabidopsis thaliana displaying altered patterns of cellulose deposition. Plant J. 7: 453-460.

Ralph, J., J. H. Grabber, and R. D. Hatfield. 1995. Lignin-ferulate cross-links in grasses: active incorporation of ferulate polysaccharide esters into ryegrass lignins. Carbohydrate Res. 275: 167-178.

Ralph, J., R. D. Hatfield, J. H. Grabber, H. G. Jung, S. Quideau, and R. F. Helm. 1998a. Cell wall cross-linking in grasses by ferulates and diferulates. po. 209-236. In N. G. Lewis and S. Sarkanen (eds.). Lignin and Lignan Biosynthesis. ACS, Washington, DC.

Ralph, J., R. D. Hatfield, J. Piquemal, N. Yahiaoui, M. Pean, C. Lapierre, and A. M. Boudet. 1998b. NMR characterization of altered lignins extracted from tobacco plants down-regulated for lignification enzymes CAD and CCR. Proc. Natl. Acad. Sci. 95: 12803-12808.

Ralph, J., J. J. MacKay, R. D. Hatfield, D. M. O'Malley, R. W. Whetten, and R. R. Sederoff. 1997. Abnormal lignin in a loblolly pine mutant. Science 277: 235-239.

Reiter, W.-D. 1994. Structure, synthesis, and function of the plant cell wall. pp. 955-988. In E. M. Meyerowitz and C. R. Somerville (eds.). Arabidopsis. Cold Spring Harbor Laboratory Press, Plainview, NY,

Reiter, W.-D., C. C. S. Chapple, and C. R. Somerville. 1993. Altered growth and cell walls in a fucose-deficient mutant of Arabidopsis. Science 261: 1032-1035.

Risser, P.G. 1996. Summary. A new frame work for prairie conservation. po.261-274. In F.B. Sampson and F. L. Knoph (eds.). Prairie Conservation. Preserving North America's most endangered ecosystem. Island Press, Washington, D.C.

Sampson, F. and F. Knopf. 1994. Prairie Conservation in North America. BioScience 44: 418-421.

Sanderson, M.A. and Wolf, D.D. 1995. Switchgrass biomass composition during morphological developmment in diverse environments. Crop Sci. 35:1432-1438.

Saxena, I. M., F. C. Lin, and R. M. Brown, Jr. 1990. Cloning and sequencing of the cellulose synthase catalytic subunit gene of Acetobacter xylinium. Plant Mol. Biol. 15: 673-683.

Service, R. F. 1998. Seed-sterilizing 'terminator technology' sows discord. Science 282:850-851.

Sewalt, V. J. H., J. W. Blount, and R. A. Dixon. 1996. Biotechnological improvement of alfalfa nutritive quality by anti-sense expression of COMT and CCOMT, methylating enzymes in lignin biosynthesis. North American Alfalfa Improv. Conf., Oklahoma City, Oklahoma,. p. 33.

Sewalt, V. J. H., W. Ni, J. W. Blount, H. G. Jung, S. A. Masoud, P. A. Howles, C. Lamb, and R. A. Dixon. 1997. Reduced lignin content and altered lignin composition in transgenic tobacco down-regulated in expression of L-phenylalanine ammonia-lyase or cinnamate 4-hydroxylase. Plant Physiol. 115: 41-50.

Shani, Z., and O. Shoseyov. 1999. Expression of cellulose binding domain (CBD) in transgenic plants increases biomass and polysaccharide biosynthesis. Impact of Molecular Biology on Crop Production and Crop Protection, Minneapolis, MN.

Shenk, J.S. and M.O. Westerhaus. 1994. The application of near infrared reflectance spectroscopy (NIRS) to forage analysis. pp. 406-449.In G. C. Fahey, Jr., M. Collins, D. R. Mertens, and L. E. Moser (eds.). Forage Quality, Evaluation, and Utilization. ASA-CSSA-SSSA, Madison, WI. 
Shenk, J. S. and M. O. Westerhaus. 1995. Forage analysis by near infrared spectroscopy. pp. 111-120. In R.F. Barnes, D.A. Miller, and C.J. Nelson (eds). Forages II: The Science of Grassland Agriculture. Iowa State University Press, Ames, IA.

Shpigel, E., L. Roiz, R. Goren, and O. Shoseyov. 1998. Bacterial cellulose-binding domain modulates in vitro elongation of different plant cells. Plant Physiol. 117: 1185-1194.

Sleper, D.A. 1987. Forage Grasses, pp.161-208. In W.R. Fehr. (ed). Principles of cultivar improvement. Macmillian Publishing Co., New York.

Sleper, D. A. and C. Chen. 1998. Molecular mapping of forage grasses. In Molecular and Cellular Technologies for forage improvement. pp.11-24. In E. C. Brummer, N. S. Hill, and C. A. Roberts (eds). CSSA Spec. Publ. 26. CSSA, Madison, WI

Steinauer, E. M. and S. L.Collins. 1996. Prairie ecology-The tallgrass prairie. p . 40-52. In F. B. Sampson and F. L. Knoph (eds.). Prairie Conservation. Preserving North America's most endangered ecosystem. Island Press, Washington, D.C.

Stewart, D., N. Yahiaouti, G. J. McDougall, K. Myton, C. Marque, A. M. Boudet, and J. Haigh. 1997. Fourier-transform infrared and Raman spectroscopic evidence for the incorporation of cinnamaldehydes into the lignin of transgenic tobacco (Nicotiana tabacum L.) plants with reduced expression of cinnamyl alcohol dehydrogenase. Planta 201: 311-318.

Stuber, C. W., M. Polacco, and M. L. Senior. 1999. Synergy of empirical breeding, markerassisted selection, and genomics to increase crop yield potential. Crop Sci. 39:1571-1583.

Surprenant, J.; D. K.Barnes, R. H. Busch and G. C. Marten. 1988. Bidirectional selection for neutral detergent fiber and yield in reed canarygrass. Can. J. Plant Sci. 68:705-712.

Tamagnone, L., A. Merida, A. Parr, S. Mackay, F. A. Culianez-Macia, K. Roberts, and C. Martin. 1998. The AmMYB308 and AmMYB330 transcription factors from Antirrhinum regulate phenylpropaniod and lignin biosynthesis in transgenic tobacco. Plant Cell 10: 135-154.

Taylor, N., P. Poindexter, W. Schneible, S. Cutler, C. Somerville, and S. Turner. 1998. Molecular characterization of irx3, a mutant deficient in cellulose deposition. 8th Int. Cell Wall Mtg., Sept.1-5, 1998, Norwich, UK, Abstr. 1.53.

Taylor, N. G., W. R. Scheible, S. Cutler, C. R. Somerville, and S. R. Turner. 1999. The irregular xylem3 locus of Arabidopsis encodes a cellulase synthase required for secondary wall synthesis. Plant Cell 11: 769-780.

Tenhaken, R., and O. Thulke. 1996. Cloning of an enzyme that synthesizes a key nucleotide-sugar precursor of hemicellulose biosynthesis from soybean: UDP-glucose dehydrogenase. Plant Physiol. 112: 1127-1134.

Theander, O., P. Aman, E. Westerlund, R. Andersson, and D. Pettersson. 1995. Total dietary fiber determined as neutral sugar residues, uronic acid residues, and Klason lignin (The Uppsala Method): collaborative study. J. AOAC Int. 78: 1030-1044.

Turner, S. R., and C. R. Somerville. 1997. Collapsed xylem phenotype of Arabidopsis identifies mutants deficient in cellulose deposition in the secondary wall. The Plant Cell 9: 689-701.

Van Soest, P. J. 1994. Nutritional Ecology of the Ruminant, Second ed. Cornell University, Ithaca, NY, p. 476.

Vignols, F., J. Rigau, M. A. Torres, M. Capellades, and P. Puigdomenech. 1995. The brown midrib (bm3) mutation in maize occurs in the gene encoding caffeic acid $O$-methyltransferase. Plant Cell 7: 407-416.

Vogel, K. P., H. J. Gorz, and F. A. Haskins. 1981. Divergent selection for in vitro dry matter digestibility in switchgrass. Crop Sci. 21:39-41.

Vogel, K. P., F. A. Haskins, H. J. Gorz, B. A. Anderson, and J. K. Ward. 1991. Registration of 'Trailblazer' switchgrass. Crop Sci. 31:1388.

Vogel, K.P. and K.J. Moore. 1993. Native North American Grasses. pp. 284-293. In J. Janick and J.E. Simon (eds). New Crops. Proc 2nd. Nat. Sym. New Crops. Indianapolis, IN. Oct. 6-9, 1991. John Wiley and Sons, Inc. New York. 
Vogel, K. P. and J. F. Pedersen. 1993. Breeding systems for cross-pollinated perennial grasses. Plant Breeding Rev.11:251-274.

Vogel, K. P. and D. A. Sleper. 1994. Alteration of plants via genetics and plant breeding. pp. 891-921. In G. C. Fahey, Jr., M. Collins, D. R. Mertens, and L. E. Moser (eds.). Forage Quality, Evaluation, and Utilization. ASA-CSSA-SSSA, Madison, WI.

Vogel, K. P., A. A. Hopkins, K. J. Moore, K. D. Johnson, and I. T. Carlson. 1996. Registration of 'Shawnee' switchgrass. Crop Sci. 36:1713.

USDA-ARS (U.S. Department of Agriculture-Agricultural Research Service). 1999. Fact SheetWhy USDA's Technology Protection System (aka 'Terminator') Benefits Agriculture. Internet site:http://www.ars.usda.gov/misc/fact.htm.

United States Patent Office. 1999. United States Patent Number 5,723,765: Control of gene expression, issued on March 31998 to Delta and Pine Land C. and the United States Department of Agriculture. Inventors: M.J. Oliver, J.E. Quisenberry, NLG Trolinder, and D.L. Keim.

Ward, M. G., J. K. Ward, B. E. Anderson, and K. P. Vogel. 1989. Grazing selectivity and in vivo digestibility of switchgrass strains selected for differing digestibility. J. Anim. Sci. 67:1418-1424.

Wilson, J. R. 1993. Organization of forage plant tissues. pp. 1- 32. In H. G. Jung, D. R. Buxton, R. D. Hatfield, and J. Ralph (eds.). Forage Cell Wall Structure and Digestibility. ASA-CSSA-SSSA, Madison, WI.

Wilson, J. R., B. Deinum, and F. M. Engels. 1991. Temperature effects on anatomy and digestibility of leaf and stem of tropical and temperate forage species. Neth. J. Agric. Sci. 39:31-48.

Wricke, G. and W. E. Weber. 1986. Quantitive genetics and selection in plant breeding. Berlin, New York: Walter de Gruyter

Yahiaoui, N., C. Marque, K. E. Myton, J. Negrel, and A. M. Boudet. 1998. Impact of different levels of cinnamyl alcohol dehydrogenase down-regulation on lignins of transgenic tobacco plants. Planta 204: 8-15.

Ye, X., S. Al-Babili, A. Klöti, J. Zhang, P. Lucca, P. Beyer, and I. Potrykus. 2000. Engineering the provitamin A (\$-carotene) biosynthetic pathway into (carotenoid -free) rice endosperm. Science 287:303-306. 


\section{INTERNAL DISTRIBUTION}

1-75. J. H. Cushman

76. Central Research Library

77-78 ESD Library (3 copies)
79-80. Laboratory Records-OSTI (2 copies)

81. Laboratory Records-RC

\section{EXTERNAL DISTRIBUTION}

82. Ray Costello, U.S. Dept. of Energy, Biomass Power Program, 1000 Independence Ave, SW, EE-13, Washington, DC 20585

83. John Ferrell, U.S. Dept. of Energy, Office of Fuels Development, 1000 Independence Avenue, EE-31/MS:6B-025 FORS, Washington, DC 20585

84. Jacob Kaminsky, U.S. Dept. of Energy, Biomass Power Program, 1000 Independence Avenue, EE-13, Washington,DC 20585

85. Sarah Sprague, U.S. Dept. of Energy, Office of Fuels Development, EE-31, 1000 Independence Avenue, Washington, DC 20585 